\title{
Controlling risk of SARS-CoV-2 infection in essential workers of enclosed food manufacturing facilities
}

Julia S. Sobolik ${ }^{1^{*}}$, Elizabeth T. Sajewski ${ }^{1}$, Lee-Ann Jaykus², D. Kane Cooper ${ }^{1}$, Ben A. Lopman ${ }^{1}$, Alicia NM. Kraay ${ }^{1}$, P. Barry Ryan ${ }^{1}$, Juan S. Leon ${ }^{1}$

${ }^{1}$ Rollins School of Public Health, Emory University, Atlanta, GA USA

${ }^{2}$ Food, Bioprocessing and Nutrition Sciences, North Carolina State University, Raleigh, NC, 27695

*Corresponding author: Julia S. Sobolik, 1518 Clifton RD, NE, Atlanta, GA USA, julia.sobolik@emory.edu, 404-727-7443

Author Contributions: J.S.S., LA.J., B.A.L., P.B.R., and J.S.L., designed research; J.S.S., A.K., D.K.C., and E.T.S., performed research; J.S.S. analyzed data; J.S.S., and J.S.L. wrote the paper; and J.S.S., E.T.S., LA.J., D.K.C., B.A.L., A.K., P.B.R., and J.S.L. reviewed the paper.

Competing Interest Statement: The authors declare no competing interest.

Classification: Social Sciences, Environmental Sciences; Biological Sciences, Agriculture Sciences

Keywords: COVID-19, quantitative microbial risk assessment, essential workers, aerosol, droplet, and fomite-mediated transmission.

This PDF file includes:

Main Text

Figures 1 to 2

Tables 1 to 3 
medRxiv preprint doi: https://doi.org/10.1101/2021.05.14.21257244; this version posted May 18, 2021. The copyright holder for this preprint

(which was not certified by peer review) is the author/funder, who has granted medRxiv a license to display the preprint in perpetuity.

It is made available under a CC-BY-NC-ND 4.0 International license .

\begin{abstract}
The SARS-CoV-2 global pandemic poses significant health risks to workers who are essential to maintaining the food supply chain. Using a quantitative risk assessment model, this study characterized the impact of risk reduction strategies for controlling SARS-CoV-2 transmission (droplet, aerosol, fomitemediated) among front-line workers in a representative enclosed food manufacturing facility. We simulated: 1) individual and cumulative SARS-CoV-2 infection risks from close contact (droplet and aerosols at 1-3m), aerosol, and fomite-mediated exposures to a susceptible worker following exposure to an infected worker during an 8h-shift; and 2) the relative reduction in SARS-CoV-2 infection risk attributed to infection control interventions (physical distancing, mask use, ventilation, surface disinfection, hand hygiene). Without mitigation measures, the SARS-CoV-2 infection risk was largest for close contact (droplet and aerosol) at $1 \mathrm{~m}(0.96,95 \% \mathrm{Cl}: 0.67-1.0)$. In comparison, risk associated with fomite $(0.26,95 \% \mathrm{Cl}: 0.10-0.56)$ or aerosol exposure alone $(0.05,95 \% \mathrm{Cl}: 0.01-0.13)$ at $1 \mathrm{~m}$ distance was substantially lower $(73-95 \%)$. At $1 \mathrm{~m}$, droplet transmission predominated over aerosol and fomite-mediated transmission, however, this changed by $3 \mathrm{~m}$, with aerosols comprising the majority of the exposure dose. Increasing physical distancing reduced risk by $84 \%$ ( 1 to $2 \mathrm{~m}$ ) and $91 \%$ ( 1 to $3 \mathrm{~m}$ ). Universal mask use reduced infection risk by $52-88 \%$, depending on mask type. Increasing ventilation (from 0.1 to $2-8$ air changes/hour) resulted in risk reductions of $14-54 \%$ $(1 \mathrm{~m})$ and $55-85 \%(2 \mathrm{~m})$. Combining these strategies, together with handwashing and surface disinfection, resulted in $<1 \%$ infection risk. Current industry SARS-CoV-2 risk reduction strategies, particularly when bundled, provide significant protection to essential food workers.
\end{abstract}

\title{
Significance Statement
}

Using mathematical modeling, we find that workers in enclosed food manufacturing facilities are at higher risk of SARS-CoV-2 infection from close contact transmission (exposure to large droplets and small aerosol particles) than fomite transmission. Thus, strategies protecting workers should prioritize close contact transmission pathways, such as physical distancing, universal mask use, and room air changes, with surface disinfection (reducing fomite transmission) and handwashing of secondary importance. Our work supports current international (EU-OSHA), domestic (FDA, OSHA), and food industry-standard guidance for managing COVID-19 transmission in essential workers in the food manufacturing sector. Although our model was designed for an indoor food manufacturing setting, it can be readily adapted to other indoor environments and infectious respiratory pathogens. 
medRxiv preprint doi: https://doi.org/10.1101/2021.05.14.21257244; this version posted May 18, 2021. The copyright holder for this preprint

(which was not certified by peer review) is the author/funder, who has granted medRxiv a license to display the preprint in perpetuity.

It is made available under a CC-BY-NC-ND 4.0 International license.

\section{Main Text}

\section{Introduction}

Essential food worker populations have been disproportionately affected by severe acute respiratory syndrome coronavirus 2 (SARS-CoV-2) illness and death $(1,2)$. In a survey of essential workers in California, the highest excess mortality increase (39\%) was among food and agriculture workers (3). Distinctive food production and processing occupational hazards may increase SARS-CoV-2 transmission, including inadequate physical distancing $(<2 \mathrm{~m})$, shared workspaces, and extended exposure durations (812 hour shifts) $(2,4)$. Protecting the health and safety of food workers is paramount for maintaining global food supply chains and consumer food security (5).

In the food industry, the relative importance of SARS-CoV-2 transmission pathways have not been quantified. Exposure to SARS-CoV-2 within food manufacturing (processing) facilities may occur through direct (droplet and aerosol) and indirect (fomite-mediated) transmission pathways (6). Droplet transmission is defined as close contact $(<2 \mathrm{~m})$ exposure to large, virus-containing particles (>100um diameter) generated by open-mouth respiratory events (e.g. coughing or sneezing) (7) that rapidly fall to the floor and/or nearby surfaces. Nearby susceptible individuals may be infected by SARS-CoV-2 through direct infectious droplet spray onto their mucous membranes (eyes, nose, mouth) or inhalation into the upper airways. Several large outbreaks in meat and poultry facilities $(1,2,8)$ have occurred in which workers were in close contact $(<2 \mathrm{~m})$ for extended durations, suggesting droplet transmission may be a key driver of SARS-CoV-2 infection risk in these settings.

In contrast to large droplets, aerosol transmission is associated with inhalation of small particles into the upper and lower respiratory tract. Small aerosol particles are historically defined as $<5-10 \mu \mathrm{m}$ in diameter, but recently recognized to include a wider range of particle sizes $(<100 \mu \mathrm{m})(9,10)$. Given the continuous range of particle sizes (11), the differentiation between aerosol and droplet sizes as defined by specific cutoff points likely remains debatable. Exposure to these aerosol particles can occur both in close contact and at further distances (up to $9 \mathrm{~m}$ ) (11). Aerosol particles are secreted during all respiratory events, especially during breathing and speaking $(12,13)$, and epidemiologic studies suggest viral accumulation and persistence during large indoor gatherings with poor ventilation (14-19). For example, SARS-CoV-2 RNA was detected in air samples from hospitals $(20,21)$ and in empirical laboratory studies, demonstrating that viable virus can remain suspended in the air for several hours $(22,23)$. Moreover, high viral shedding, including prior to symptom onset $(24,25)$, has important implications for both droplet and aerosol transmission.

Compared to direct transmission, indirect transmission via contaminated fomite surfaces (26-28) is considered less common, but possible, for SARS-CoV-2 (29, 30). For example, SARS-CoV-2 viral RNA has been detected on surfaces in various settings $(21,31-33)$ and laboratory studies found variable persistence of virus on fomites (up to $72 \mathrm{~h}$ ) across different surface types (22). While detection of RNA is not indicative of infectious virus (34) and laboratory conditions may not reflect viral persistence in real life scenarios $(35,36)$, frequent food worker tactile events and shared workstations warrant investigating the role of fomite-mediated transmission in food production and processing settings.

U.S. and international regulatory bodies (U.S. Occupational Safety and Health Administration [OSHA], European Union-OSHA), food safety agencies (USDA, FDA) and the food industry have issued infection control guidance for worker safety in food production and processing facilities, including symptom screening, physical distancing, mask use, and enhanced surface disinfection and handwashing practices (37-39). These measures pair with existing food safety measures under the FDA's Food Safety Modernization Act, which provide standards for sick worker furlough, surface disinfection, and hand hygiene (handwashing, glove use) (40). Empirical and modeling studies suggest physical distancing $(41,42)$, mask use (43-47), and hand washing and surface disinfection (48-50) are effective measures against SARSCoV-2 transmission. However, evidence is lacking to guide the food industry on the relative importance of these interventions on SARS-CoV-2 transmission among essential workers within food manufacturing facilities. 
medRxiv preprint doi: https://doi.org/10.1101/2021.05.14.21257244; this version posted May 18, 2021. The copyright holder for this preprint

(which was not certified by peer review) is the author/funder, who has granted medRxiv a license to display the preprint in perpetuity.

It is made available under a CC-BY-NC-ND 4.0 International license .

Quantitative microbial risk assessment (QMRA) is a mathematical modeling framework used to evaluate health risks associated with direct and indirect transmission pathways and to provide insight into efficacy of infection control strategies. Commonly applied in the food and environmental safety sectors (51-55), QMRA models have recently been used to characterize SARS-CoV-2 risk in healthcare $(18,56,57)$, wastewater treatment facilities $(58,59)$, and community-based fomite transmission $(50,60,61)$, but not yet in the food manufacturing setting. In this study, a stochastic QMRA model was used to quantify the impact of risk reduction measures (physical distancing, masking, ventilation, surface disinfection, and hand hygiene) for controlling SARS-CoV-2 transmission (droplet, aerosol, fomite-mediated) among essential (front-line) workers in a representative enclosed food manufacturing facility. This work advances the evidence-base for effective risk mitigation strategies currently implemented by the food industry and can be used to inform best practices for protecting essential workers.

\section{Results}

\subsection{Relative contribution of SARS-CoV-2 transmission routes in enclosed food manufacturing facilities with a coughing infected worker}

Assuming a symptomatic infected worker (cough frequency ranged from 10-39 coughs per hour [63, 109]), we investigated the relative contribution of each transmission route (aerosol, droplet, fomite) by the distance travelled for each size class of expelled infectious particles for $1 \mathrm{~h}$ and cumulative $8 \mathrm{~h}$ exposures (Table 1). At $8 \mathrm{~h}$ exposure and $1 \mathrm{~m}$ distance between the infected and susceptible individuals, droplets $(\geq 50 \mu \mathrm{m})$ contributed $90 \%$ (absolute number: 478, 95\% Cl: [156-1,460]) of the infectious viral load, followed by aerosols $(<50 \mu \mathrm{m})$ contributing $1.3 \%$ (absolute number: $7.0,95 \% \mathrm{Cl}$ : [2-21]) and the remaining $8.3 \%$ of the infectious virus load coming from droplet and aerosol fall-out onto fomites (absolute number: $44,95 \% \mathrm{Cl}$ : [16-122]). At 2 and $3 \mathrm{~m}$, the relative contribution of each transmission route to infectious virus load shifted to favor aerosols (31-59\%) and fomites (25-48\%), although the fomite and aerosol absolute viral load at 2 and $3 \mathrm{~m}$ (3-11 PFUs) was $91-99 \%$ lower than the droplet absolute viral load at $1 \mathrm{~m}$ (478 PFU). The patterns for $1 \mathrm{~h}$ were similar (Table 1). Thus, the relative contribution of each mechanism of infectious particle spread was influenced by distance, with infectious droplet transmission representing the largest contribution to dose at $1 \mathrm{~m}$.

Combining aerosol, droplet, and fomite-mediated transmission pathways resulted in combined risk estimates for exposures at near distances $(1 \mathrm{~m}, 2 \mathrm{~m}$, and $3 \mathrm{~m})$ and beyond (>3m, aerosols only, Figure 1B). Considering combined risks associated with close contact transmission $(\leq 3 \mathrm{~m})$ at cumulative $8 \mathrm{~h}$ exposures, $1 \mathrm{~m}$ distance $(0.98,95 \% \mathrm{Cl}$ : [0.76-1.0]) resulted in the greatest risk, followed by $2 \mathrm{~m}(0.15,95 \% \mathrm{Cl}$ : $0.07-$ $0.32])$ and $3 \mathrm{~m}(0.09,95 \% \mathrm{Cl}$ : [0.04-0.18]) distances. Infection risks associated with aerosol and droplet transmission, without fomite-mediated transmission, remained elevated at $1 \mathrm{~m}:(0.96,95 \% \mathrm{Cl}: 0.67-1.0)$. Aerosol transmission alone resulted in substantially lower combined infection risks (8h: $0.05,95 \% \mathrm{Cl}$ : [0.010.13]) (Figure 1B). The combined infection risk associated with small, aerosolized particles $(<50 \mu m)$ resulting from closed mouth, nasal breathing events (8h: $2 \times 10^{-4}, 95 \% \mathrm{Cl}$ : $\left.\left[6 \times 10^{-5}-6 \times 10^{-4}\right]\right)$ was smaller than the risk from aerosolized particles $(<50 \mu \mathrm{m})$ resulting from coughing events (8h: $0.05,95 \% \mathrm{Cl}:$ [0.014-0.13]) (SI Appendix, Figure S2). While we initially intended to conduct all of our analyses with either a symptomatic (coughing) or asymptomatic (breathing) infected worker, given the nominal combined infection risk for breathing in the absence of any interventions, we determined coughing events appear to drive the risk within the context of this simulated manufacturing facility. Thus, we proceeded with only a symptomatic (coughing) infected worker for analyses moving forward. Fomite-mediated transmission associated with direct tactile events with a work surface contaminated from aerosol and droplet virus fallout resulted in modest infection risks (8h): ranging from $1 \mathrm{~m}(0.26,95 \% \mathrm{Cl}$ : [0.10-0.56]), $2 \mathrm{~m}$ : $(0.07,95 \% \mathrm{Cl}$ : [0.02-0.20]),

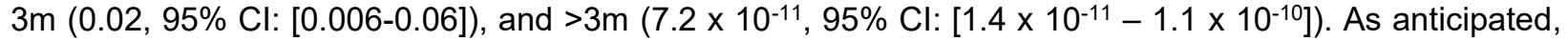
combined risks as well as risks associated with aerosol and fomite-mediated transmission accumulated with increasing exposure time from 1 to 8 hours (Figure 1B). In particular, combined risks at $1 \mathrm{~m}$ distancing started to plateau near $5 \mathrm{~h}$ exposure and appeared to reach the exponential dose-response upper bound of the probability of infection equal to 1.0 after $8 \mathrm{~h}$ of cumulative exposure from a coughing infected worker. Considerable variability in the infection risk estimates were noted, as represented by wide $95 \%$ confidence intervals (SI Appendix, Table S1). This is consistent with our sensitivity analyses (SI Appendix, Table S3), which identified variability propagating through the model associated with only a few parameters (i.e. virus 
medRxiv preprint doi: https://doi.org/10.1101/2021.05.14.21257244; this version posted May 18, 2021. The copyright holder for this preprint

(which was not certified by peer review) is the author/funder, who has granted medRxiv a license to display the preprint in perpetuity.

It is made available under a CC-BY-NC-ND 4.0 International license .

titer in saliva, cough frequency, inhalation and deposition rate), all of which were found to be strongly positively correlated with infection risk.

\subsection{Comparison of $\mathbf{R}_{0}$ values derived from SARS-CoV-2 combined transmission risks}

To assess the order of magnitude of these SARS-CoV-2 infection risk estimates at the population-level, using a 7-day infectious period, we converted the combined transmission risk estimates to population-level $R_{0}$ values. At $1 \mathrm{~m}$, $R_{0}$ values ranged from 2.38 (1h) to 6.83 (8h) (SI Appendix, Table S4). As all combined risk estimates (exposures ranging from $1-8 \mathrm{~h}$ ) at $1 \mathrm{~m}$ distancing, when converted to Ro values, were $>1$, this suggests that SARS-CoV-2 transmission would be sustained when workers are in close contact to each other. An Ro value of 1.07 (95\% Cl: 0.48-2.2) was estimated for $2 \mathrm{~m}$ exposures with 8 h cumulative risks. Distances of $3 \mathrm{~m}$ and beyond were found to have all $R_{0}$ values $<1$. These model derived $R_{0}$ values were consistent with reported population-level disease transmission events with $R_{0}$ values ranging from: 2.3 to 11 (62-64). Despite heterogeneity across attack rates and outbreak scenarios, we found that our risk estimates, when scaled, were representative of observed SARS-CoV-2 transmission dynamics at the population level.

\subsection{Impact of individual interventions targeting combined risk}

Increasing physical distancing resulted in substantial combined risk reductions following $1 \mathrm{~h}$ exposure. An additional $1 \mathrm{~m}$ distancing from 1 to $2 \mathrm{~m}$ led to a $97 \%$ reduction in risk and from 2 to $3 \mathrm{~m}$ led to a $35 \%$ reduction in risk. Increasing physical distancing by $2 \mathrm{~m}$ from 1 to $3 \mathrm{~m}$ resulted in a $98 \%$ risk reduction (Figure $1 \mathrm{~B}, \mathrm{SI}$ Appendix, Table S2). A similar trend in risk reductions was found following an $8 \mathrm{~h}$ exposure: an additional $1 \mathrm{~m}$ distancing from 1 to $2 \mathrm{~m}$ led to a $84 \%$ reduction in risk and from 2 to $3 \mathrm{~m}$ led to a $43 \%$ reduction in risk. Increasing physical distancing by $2 \mathrm{~m}$ from 1 to $3 \mathrm{~m}$ resulted in a $91 \%$ risk reduction. These analyses demonstrated that physical distancing $2 \mathrm{~m}$ and beyond provided the greatest relative reduction in combined infection risk.

Universal mask use at $1 \mathrm{~m}$ distance following $8 \mathrm{~h}$ cumulative exposure with a coughing infected worker reduced combined infection risk by $52 \%$ (cloth mask: 0.47 risk, $95 \% \mathrm{Cl}$ : $0.20-0.87$ ), $64 \%$ (surgical mask: 0.35 risk, $95 \% \mathrm{Cl}$ : $0.12-0.76$ ), $88 \%$ (double masking [surgical followed by cloth]: 0.12 risk, $95 \% \mathrm{Cl}: 0.03-$ 0.55 ), and $99 \%$ (N95 respirator: 0.01 risk, $95 \% \mathrm{Cl}: 0.004-0.02$ ), relative to no mask use (Table 2), leading to absolute risk of infection at $1 \mathrm{~m}$ of $0.01-0.47$, depending on mask type. Combining mask use and physical distancing resulted in enhanced risk reduction, suggesting a synergistic effect between these two interventions. For example, following $8 \mathrm{~h}$ cumulative exposure, distancing from $1-2 \mathrm{~m}$ paired with mask use resulted in risk reductions of $91 \%$ across all mask types. Physical distancing from $2-3 \mathrm{~m}$ resulted in risk reductions ranging from $53-61 \%$ reduction depending on the mask type. Physical distancing from 1-3m resulted in risk reductions ranging from $96-97 \%$ reduction depending on the mask type. In all cases with the exception of N95 respirators, physical distancing paired with mask use resulted in a greater risk reduction than distance or mask use alone.

To evaluate the impact of ventilation on combined infection risk following an $8 \mathrm{~h}$ exposure with an infected worker, we increased air change rates per hour from 2 to $8 \mathrm{ACH}$ (Figure 2). Compared to baseline (ACH 0.1 ), increasing air change to between 2 to $8 \mathrm{ACH}$ resulted in a percent reduction in combined infection risk at: $1 \mathrm{~m}$ (mean of $2-8 \mathrm{ACH}: 36 \%$, range: $14 \%-54 \%$ ), $2 \mathrm{~m}$ (mean of $2-8 \mathrm{ACH}: 74 \%$, range: $55 \%-85 \%$ ), $3 \mathrm{~m}$ (mean of 2-8 ACH: $77 \%$, range: $60 \%-87 \%$ ), and $>3 \mathrm{~m}$ (mean of $2-8 \mathrm{ACH}: 82 \%$, range: $69 \%-90 \%$ ). Similar to mask usage, reductions in the combined infection risk were enhanced when the susceptible worker was $2 \mathrm{~m}$ or $3 \mathrm{~m}$, compared to $1 \mathrm{~m}$, distance away from the infected worker in the presence of increasing air exchange. Following 8 cumulative exposure, distancing from 1-2m resulted in risk reductions of $92-95 \%$ for $\mathrm{ACH}$ ranging from 2-8. Physical distancing from $2-3 \mathrm{~m}$ produced risk reductions ranging from $50-51 \%$ for 2-8 ACH. Combining the two physical distancing ranges $(1-3 \mathrm{~m})$ produced risk reductions ranging from $96-$ $98 \%$ for 2-8 ACH. Rank prioritizing these single interventions suggests physical distancing, followed by mask use, and then increasing facility ventilation results in the largest combined risk reductions to a susceptible worker after an 8h-shift with a coughing infected worker. However, the impact of distancing from $2 \mathrm{~m}$ and beyond was notably enhanced when paired with mask use (any mask type) or air change rates $(\geq 2 \mathrm{ACH})$, which resulted in combined risk reductions $>91 \%$.

\subsection{Impact of individual interventions targeting fomite-mediated risk}


medRxiv preprint doi: https://doi.org/10.1101/2021.05.14.21257244; this version posted May 18, 2021. The copyright holder for this preprint

(which was not certified by peer review) is the author/funder, who has granted medRxiv a license to display the preprint in perpetuity.

It is made available under a CC-BY-NC-ND 4.0 International license .

Although the relative contribution of fomites to infectious dose was low compared to droplet transmission (Table 1), fomite-mediated transmission does contribute to worker risk, particularly at close exposures. Thus, we investigated interventions specifically targeting fomite-mediated, 8h cumulative exposures from a coughing infected worker at $1 \mathrm{~m}$ distance (worst-case scenario). Similar to the close contact and aerosol transmission pathways, mask use effectively reduced fomite-mediated transmission. Following $8 \mathrm{~h}$ cumulative exposure at $1 \mathrm{~m}$, mask use reduced fomite-mediated infection risk by $62 \%$ (cloth mask: 0.10 risk, 95\% Cl: [0.03-0.25]), 63\% (surgical mask: 0.09 risk, 95\% Cl: [0.03-0.25]), 88\% (double masking [surgical followed by cloth]: 0.03 risk, $95 \% \mathrm{Cl}$ : [0.005-0.15]), and 99\% (N95 respirator: 0.003 risk, $95 \% \mathrm{Cl}$ : [0.001-0.008]), relative to no mask use. Handwashing (2 $\log _{10}$ virus removal efficacy) and hand sanitizer ( $3 \log _{10}$ virus removal efficacy) use resulted in large fomite-mediated risk reductions relative to no intervention: handwashing hourly $(98.8 \%$ reduction; 0.003 risk, $95 \% \mathrm{Cl}$ : [0.001-0.008]) and alcohol-based hand sanitizer hourly (99.88\% reduction; $3 \times 10^{-4}$ risk, $95 \% \mathrm{Cl}$ : [1 $\left.1 \times 10^{-4}-8 \times 10^{-4}\right]$ ) (SI Appendix, Figure S3). Hourly glove changes (assuming handwashing completely removed all viral contamination and was performed before donning clean gloves) mitigated all SARS-CoV-2 fomite-mediated risk (data not shown). Only hourly surface disinfection (the most frequent surface disinfection scenario tested) resulted in fomitemediated risk reductions comparable to those achieved by handwashing: hourly surface disinfection ( $3 \log _{10}$ virus removal efficacy) (99.96\% reduction; $1 \times 10^{-4}$ risk, $95 \% \mathrm{Cl}$ : $\left[3 \times 10^{-5}-3 \times 10^{-4}\right]$ ) and hourly surface disinfection (4log 10 virus removal) (99.99\% reduction; $1 \times 10^{-5}$ risk, $95 \% \mathrm{Cl}$ : $\left[3 \times 10^{-6}-3 \times 10^{-5}\right]$ ), relative to no intervention (SI Appendix, Figure S3).

\subsection{Impact of bundled risk mitigation strategies targeting combined infection risk}

Our survey of food manufacturing facilities and discussions with food industry experts (data not shown) indicated that various, simultaneous COVID-19 specific infection control measures (mask use, physical distancing, air changes per hour, hand hygiene, surface disinfection, sick worker furlough) have been consistently implemented in food production and processing facilities, in practice. Bundled strategies of physical distancing of $2 \mathrm{~m}$, universal mask wearing (cloth, surgical, or double masking), and at least $2 \mathrm{ACH}$ (industry standard), combined with handwashing (hourly) and surface disinfection (twice per shift, $4 \mathrm{~h}$ and $8 \mathrm{~h}$ ) resulted in combined infection risks less than $1 \%$ in an 8 h-shift (Table 3 ). Comparable combined infection risks $(<1 \%)$ were achieved with bundled strategies incorporating reduced frequencies of surface disinfection (once per shift) and hand hygiene (twice per shift); reduced efficacies of surface disinfection (1 to $3 \log _{10}$ virus removal efficacy); and with hand sanitizer used interchangeably with handwashing (data not shown), in addition to mask use and $\mathrm{ACH}$. If physical distancing is not possible, at $1 \mathrm{~m}$ distancing, the largest combined infection risk reduction of $98 \%$ resulted from double mask use with $6 \mathrm{ACH}$ (risk: $0.02,95 \% \mathrm{Cl}$ : [0.002-0.14]), relative to no interventions.

\subsection{Sensitivity analyses}

Sensitivity analyses were conducted to identify the most influential parameters for SARS-CoV-2 infection risk, reported as Spearman's correlation coefficients. The parameters with the greatest contribution to infection risk were consistent across the aerosol and droplet transmission pathways and included the SARS-CoV-2 titer in saliva (aerosol $\rho=0.58$; droplet $\rho=0.73$ ); cough frequency of the infected worker (aerosol $\rho=0.24$; droplet $\rho=0.30$ ); inhalation rate (aerosol $\rho=0.19$; droplet $\rho=0.16$ ); and lung deposition rate (aerosol $\rho=0.21$; droplet $\rho=0.16$ ) (SI Appendix, Figure S1). The dose-response $k$ parameter was found to have a moderate correlation with SARS-CoV-2 infection risk (droplet $\rho=0.36$ ). The parameters with the greatest impact on reducing infection risk included mask filtration efficiency $(\rho=-0.13$ to -0.16$)$ ) and the number of air changes per hour $(\rho=-0.52$ to -0.35$)$. Notably the parameters describing tactile events, such as transfer efficiency and number of contacts, generally had smaller effects $(\rho=-0.002$ to 0.005$)$ on the infection risk estimates.

We also evaluated the contribution of individual parameters to the overall variability associated with the estimated infection risk. Variability, representing temporal, geographical, and individual heterogeneity, was generally quite low for each individual parameter, with the largest values associated with: (1) the distribution of particle sizes found in a cough or breathing event; (2) cough frequency; (3) masking efficacies; (4) room air exchange; (5) transfer efficiencies from fomite-to-hand; and (5) transfer efficiencies from hand-to-face mucous membranes. (SI Appendix, Table S3). The overall impact of variability on aerosol and droplet infection risk estimates, defined as the variability ratio $\left(97.5^{\text {th }}\right.$ model estimate/the median model estimate), were modest (variability ratio: 6.8 to 10.2). For the fomite-mediated transmission pathway, considerable 
medRxiv preprint doi: https://doi.org/10.1101/2021.05.14.21257244; this version posted May 18, 2021. The copyright holder for this preprint

(which was not certified by peer review) is the author/funder, who has granted medRxiv a license to display the preprint in perpetuity. It is made available under a CC-BY-NC-ND 4.0 International license .

variability was found to propagate through the simulated viral concentration on the fomite surface, to the viral concentration on hands, and ultimately for the fomite-mediated risk.

\section{Discussion}

In this study, a stochastic quantitative risk assessment model was used to quantify the impact of risk reduction strategies (physical distancing, masking, ventilation, surface disinfection, and hand hygiene) for controlling SARS-CoV-2 transmission (droplet, aerosol, fomite-mediated) among essential (front-line) workers in a representative enclosed food manufacturing facility. Collectively, our modeling results indicate that droplets were the dominant transmission mode $(90 \%)$ at $1 \mathrm{~m}$ distance, delivering the highest infectious viral load to essential food workers during $8 \mathrm{~h}$-shifts, relative to aerosol and fomite-mediated routes (1-8\%). In comparison, at distances $2 \mathrm{~m}$ and beyond, the viral load shifted to aerosol and fomite-mediated transmission. However, their absolute dose contribution (aerosol viral load: 7.0, 95\% Cl: [2-21]; fomitemediated viral load: $44,95 \% \mathrm{Cl}$ : [16-122]) remained 91-99\% lower than droplet-mediated transmission at $1 \mathrm{~m}$, and absolute risk from all pathways combined was far lower than risk at $1 \mathrm{~m}$. Among the individual interventions, physical distancing ( $2 \mathrm{~m}$ and beyond) and mask use resulted in the largest risk reductions to a food worker. Bundled interventions (at least $2 \mathrm{ACH}, 2 \mathrm{~m}$ physical distancing, universal mask use, hand hygiene and surface disinfection) reduced essential food worker risk to below $1 \%$ for an $8 \mathrm{~h}$ cumulative exposure in an enclosed food manufacturing facility.

The droplet-mediated transmission pathway at $1 \mathrm{~m}$ contributed at least a 11-fold higher viral load than fomite-mediated or aerosol pathways at $1 \mathrm{~m}$ ( $1 \mathrm{~h}$ and $8 \mathrm{~h}$ cumulative exposures), translating to a higher attributable risk of infection. Two mechanisms explaining this result include the particle size distribution generated during cough events and the delivery of the highest infectious dose in these cough-generated particles. While cough respiratory events generate both small and large particles, large particles (droplets $>50 \mu \mathrm{m}$ ) represent a higher proportion of the particles released while coughing relative to other respiratory events (65). These large droplets, which have a larger volume, comprise the majority $(99.9 \%)$ of the fluid volume expelled during a cough event (66). While empirical work has shown influenza virus-infected patients generate small aerosols $(<5 \mu \mathrm{m})$ containing viable virus $(67-70)$, to date, the distribution of infectious SARS-CoV-2 in aerosols and droplets has not been validated. Using a Poisson distribution to estimate the number of viruses enclosed in a droplet, Wang et al., estimated that upon particle emission, viruses were mostly contained in droplets $(>10 \mu \mathrm{m})$. However, these particle sizes were predicted to reduce to approximately $2 \mu \mathrm{m}$ in size following evaporation (71). While additional empirical studies are needed to confirm the size-dependent concentration and infectivity of SARS-CoV-2 in respiratory particles, we chose to implement a conservative approach by assuming uniform virus concentration across particle sizes. We speculate this approach could potentially lead to heightened "worst-case scenario" risk estimates associated with close contact droplet exposures. However, the efficacy of interventions and the relative risk reductions associated with these interventions should remain reliable as any potential biases introduced due to virus concentration across particle sizes would be incorporated into both the intervention and control risk estimates (72).

Although our model showed that droplets $(50-750 \mu \mathrm{m})$ played a larger role in close contact $(1 \mathrm{~m})$ transmission, Azimi et al. reported no significant difference between larger respiratory droplets ( $>5$ to 10 $\mu \mathrm{m}$ ) (median: $40 \%$, mean: $50 \%$ ) and smaller respiratory aerosols $(<10 \mu \mathrm{m})$ (median: $60 \%$, mean: $50 \%$ ) and their contribution to SARS-CoV-2 transmission aboard a cruise ship prior to passenger quarantine $(p=0.32)$. Differences in modeling certain parameters, i.e., the proportion of aerosols to droplets emitted during a respiratory event and estimating the infectious dose, rather than using the existing SARS-CoV doseresponse model, likely explain differences in findings. For our model, we determined that any uncertainty or variability introduced by extrapolating from a SARS-CoV dose-response to SARS-CoV-2 was nominal given the similarities between the viruses (high genetic and amino acid homology) (73) and shared transmission pathways. In a clinical setting, Jones et al., found that the relative contribution to overall infection risk was higher for aerosols $57 \%(33,82 \%)$ versus droplet $35 \%(12,55 \%)$ transmission (18). However, Jones et al. modeled a substantially smaller room volume $\left(20-50 \mathrm{~m}^{3}\right)$, incorporated continuous virus emission of aerosols $(<10 \mu \mathrm{m})$ via exhaled breath in addition to aerosols and droplets generated from coughing, and assumed droplet particles have $50 \%$ the virus concentration of aerosols (compared to our 
medRxiv preprint doi: https://doi.org/10.1101/2021.05.14.21257244; this version posted May 18, 2021. The copyright holder for this preprint

(which was not certified by peer review) is the author/funder, who has granted medRxiv a license to display the preprint in perpetuity. It is made available under a CC-BY-NC-ND 4.0 International license .

assumption of equal virus concentration across particles). Such differences between the results of various risk modeling studies illustrate the sensitivity of risk estimates to key exposure parameters and the challenge in determining aerosol and droplet exposure attribution, which is likely context-specific.

While detection of SARS-CoV-2 on surfaces (74) continues to suggest the potential for fomite-mediated transmission, our model estimated only a very modest role for fomite-mediated transmission in enclosed food manufacturing facilities, with fomites accounting for $<1 \%$ to $10 \%$ ( $1 \mathrm{~h}$ exposure) of the viral load (Table 1). These results are in the range of those reported in other studies across diverse settings. In a clinical setting, fomite-mediated transmission was the lowest contributor to overall SARS-CoV-2 infection risk, representing $8.2 \%$ of the total transmission risk during a single patient care activity (18). Moreover, during a cruise ship outbreak, the median contribution of fomite transmission to infected cases was estimated to be $21 \%(17)$. Translating exposure dose to infection risk, our study also found fomite-mediated transmission resulted in low SARS-CoV-2 infection risks, as expected, following $1 \mathrm{~h}$ exposure at $1 \mathrm{~m}: 0.003395 \% \mathrm{Cl}$ : [0.001-0.009]. However, following 8h cumulative exposure at $1 \mathrm{~m}$, fomite-mediated risk increased to 0.26 $95 \% \mathrm{Cl}$ : [0.10-0.56]. This infection risk translated to an $\mathrm{R}_{0}>1$ (1.8, 95\% Cl: $\left.0.71-3.9\right)$, which underscores the potential for increased risk with long exposure durations and suggests that in the situations for when droplet transmission risk is high, fomite transmission risk will also be high, potentially leading to competing or multiple pathway transmission dynamics. Our $1 \mathrm{~h}$ fomite-mediated results are consistent with Wilson et al., who found fomite-mediated infection risk was approximately $1.0 \times 10^{-3}$ for a single hand-to-fomite scenario with high SARS-CoV-2 bioburden and no surface disinfection (50). In agreement with the low contribution of fomite-mediated risk, Pitol et al., (60) and Harvey et al., (61) reported fomite-mediated risks associated with direct tactile events in community spaces (bus stations, gas stations, playgrounds) and on high touch non-porous surfaces (crosswalk buttons, trash can handles, door handles) ranging from 1.6x104 to $5.6 \times 10^{-9}$. These lower risk estimates likely result from both studies simulating a single direct tactile event in a low prevalence community setting, whereas our model accounted for multiple tactile events over an $8 \mathrm{~h}$ cumulative shift with a confirmed SARS-CoV-2 infected worker during their peak viral shedding period (20). Although heterogeneity in fomite-mediated infection risk is likely context-specific (i.e. depends on SARSCoV-2 community prevalence, degree of surface contamination, types of initiating events [i.e., breathing vs. coughing], etc.), increasingly findings suggest that fomites are a relatively less important transmission pathway than are direct and indirect respiratory exposures.

The distance between infected and susceptible individuals was a major driver of infection risk in our model. Laboratory and modeling studies $(75,76)$ suggest that the highest concentrated exposures to both droplet and aerosol respiratory particles occur when within $1 \mathrm{~m}$ of an infected individual. Consistent with these studies, our median SARS-CoV-2 infection risk was highest with close contact (droplet and aerosol) transmission at $1 \mathrm{~m}$ with exposures ranging from $1 \mathrm{~h}:(0.3495 \% \mathrm{Cl}:[0.13-0.71])$ to cumulative $8 \mathrm{~h}:(0.9695 \%$ Cl: [0.67-0.99]). Similar findings have been reported in a clinical setting, with exposure in the "near-patient zone" resulting in a mean infection risk of $0.3895 \% \mathrm{Cl}(0.18,0.53)$ from a single patient care activity (18). Similarly, in a recreational setting, close contact transmission (droplet and aerosol exposures) was predominant over other transmission modes when individuals were restricted to their close quarter cruise ship cabins ( 14 sq. m) (17). Moreover, we found risk estimates decreased by over $80 \%$ when increasing the distance by $1 \mathrm{~m}$ between the workers. This protective effect was consistent with previous studies finding that $>1 \mathrm{~m}$ physical distances were associated with large risk reductions and distances of $>2 \mathrm{~m}$ could be even more effective $(42,77)$.

In addition to distance, our findings suggest that facility space and layout also contribute to the relative and absolute risk of virus transmission to workers. For instance, at distances beyond large droplet exposures $(>1 \mathrm{~m})$, we found a greater contribution of the infectious dose derived from the aerosol and fomite mediated transmission modes. These results align with reports of virus-laden aerosols $(<50-100 \mu \mathrm{m})$ capable of accumulating in the air over time in enclosed facilities (78). Despite this shift towards aerosol transmission at distances $>1 \mathrm{~m}$, surprisingly, we found the relative infection risks associated with both aerosol and fomitemediated transmission remained small. We hypothesize that large indoor spaces, like enclosed food manufacturing facilities, attenuate aerosol accumulation through dilution across the facility space. For example, a model of the seafood market in Wuhan found reduced median SARS-CoV-2 infection risks after $1 \mathrm{~h}$ exposure $\left(2.23 \times 10^{-5}\right.$ [95\% Cl: $1.90 \times 10^{-6}$ to $\left.\left.2.34 \times 10^{-4}\right]\right)$, likely due to aerosols disseminated over the $>3000$ cubic meter space (79). Similarly, our model represented a 1000 cubic meter facility, in which we 
medRxiv preprint doi: https://doi.org/10.1101/2021.05.14.21257244; this version posted May 18, 2021. The copyright holder for this preprint

(which was not certified by peer review) is the author/funder, who has granted medRxiv a license to display the preprint in perpetuity. It is made available under a CC-BY-NC-ND 4.0 International license .

assumed instantaneous mixing of the room air with homogenous distribution of aerosol particles throughout the facility. Re-running the model using a smaller space (37 cubic meters) produced a 17-fold increase in aerosol transmission-mediated risk $(0.73,95 \% \mathrm{Cl}$ : 0.33-0.98), suggesting small enclosed spaces (with minimal ventilation, $\mathrm{ACH}$ 0.1) may accelerate accumulation of virus-laden aerosols (data not shown). Taken together, these results highlight the importance of increased distance as an effective risk mitigation strategy and the need to contextualize facility spaces when discussing relative infection risks.

The risk reduction effect of universal mask use in our study is consistent with previous empirical $(42,77)$ and laboratory-based experiments (44-47). In our study, universal double masking (surgical mask layered underneath a cloth mask) by both the infected and susceptible workers reduced risk by 88 to $98 \%(1 \mathrm{~m}$ to $>3 \mathrm{~m}$ ). These findings are consistent with those reported by Brooks et al., where both the infected and susceptible individuals were fitted with double masks and the cumulative exposure to the susceptible individual was reduced by $96.4 \%(S D=0.02)(80)$. Mask effectiveness is also dependent on individuals adhering to proper mask use (e.g. minimizing adjustment or touching the front of the mask, wearing the mask over the nose and mouth). Of course, proper mask use and adherence is necessary in order to realize the full benefit of masking in COVID-19 transmission risk reduction. While we assumed $100 \%$ mask compliance, this model could be used to evaluate varying levels of mask compliance and the impact on infection risk when only the infected worker uses a mask and not the susceptible worker, and vice versa.

Increasing ventilation in the facility, as expressed as the number of air changes per hour (ACH), resulted in a decreased infection risk, especially when combined with physical distancing and mask use. Consistent with recent work by Zhang et al. (79), Kennedy et al. (81), and Curtius et al. (82), these findings advance a growing body of evidence linking the association between ventilation, air movements in buildings, and the transmission of infectious diseases (measles, tuberculosis, influenza, and SARS) with primary respiratory exposure routes (83). Notably, poor room ventilation was specifically identified as a contributing factor in a SARS-CoV-2 outbreak in a German meat packing facility (84). A well-ventilated indoor room with frequent fresh air changes can prevent the accumulation of virus-laden aerosols $(<50-100 \mu \mathrm{m})(78)$, which have been demonstrated under controlled laboratory settings to remain suspended in the air for many seconds to hours (22); it also reduces the potential for super-spreader events $(16,85-87)$. Our findings advance the evidence-base of current recommendations to reduce aerosol-mediated transmission of SARS-CoV-2 (88, 89) which can be accomplished by increased ventilation (providing outdoor air to a space), avoiding air recirculation, and use of air cleaning and disinfection devices $(88,89)$. It is important to note, however, that the use of simpler interventions (masking and distancing) provided greater risk reduction than did increasing $\mathrm{ACH}$ alone, which would ultimately be a more expensive engineering investment. As most manufacturing facilities already implement 2-6 ACH as part of their standard operating procedures, prior to extensive ventilation investments, more study is needed on aerosol transmission dynamics and the value of targeted methods designed to increase ventilation in food manufacturing settings.

An important contribution of our work is quantitatively demonstrating that bundled interventions are highly effective infection control measures within enclosed food manufacturing facilities. Compliance with all standard recommendations (physical distance, universal mask usage, increased ventilation, handwashing, and surface disinfection) was found to reduce worker risk to under $1 \%$ in an $8 \mathrm{~h}$-shift. This work supports the efficacy of these bundled interventions. The high efficacy of the combined interventions involving masks and physical distancing is of particular interest given their relatively low cost, high-impact risk mitigation potential, and ease of scaling across diverse food manufacturing settings. Continued utilization of these two mitigation strategies is especially salient given uncertainties surrounding the emergence of SARS-CoV2 variants, vaccine efficacy against the variants, and duration of immunity. Our model may be particularly helpful in informing decision-making for facility managers to prioritize which interventions to keep in place, and which to alter or stop, post-vaccination. The efficacy of advanced interventions, such as use of HEPA filtration (90) or far-UVC light inactivation (91) in controlling COVID-19 disease risk in this essential workforce can easily be incorporated in future simulations, as can the impact of various vaccination strategies.

Strengths of our model include a detailed exposure assessment design of food production and processing facilities; well-characterized human-environment interactions based on direct observation from prior fieldwork; vetting by industry and academic partners; and an extensive validation (e.g. scaling risk estimates 
medRxiv preprint doi: https://doi.org/10.1101/2021.05.14.21257244; this version posted May 18, 2021. The copyright holder for this preprint

(which was not certified by peer review) is the author/funder, who has granted medRxiv a license to display the preprint in perpetuity. It is made available under a CC-BY-NC-ND 4.0 International license .

to population-level $R_{0}$ ) and calibration, steps that are not routinely done in QMRA models. This design enabled evaluating the relative contribution of each transmission pathway (droplet, aerosol, and fomitemediated), generating combined risk estimates from SARS-CoV-2 exposures, and ultimately prioritizing evidence-based risk mitigation strategies informed by federal worker health and safety guidelines $(92,93)$ for food manufacturing facilities. A final strength of our model was incorporating new evidence from the field of aerosol physics to define aerosols and droplets beyond the classical cutoff of $\sim 10 \mu \mathrm{m}$. Regarding limitations, the first is that at the time of this writing, there was no dose-response model specific to SARSCoV-2. To address this, we leveraged the dose-response model for SARS and applied the upper $99.5 \%$ bound from 10,000 bootstrap iterations for the optimized $k$ parameter. This translated into an ID 50 dose of 100 infectious virus particles and falls within the documented $I D_{50}$ range of 10-1000 infectious doses from animal and human studies for non-SARS-CoV and SARS (94). A second limitation was that few empirical studies have characterized respiratory particle distance traveled by size. Understanding the dynamics of infectious virus-laden respiratory particles at different distances, especially accounting for air transport dynamics within a respiratory event $(11,75)$, is paramount to characterizing risk and evaluating effective intervention strategies. Certainly, this is a rapidly evolving field and the model can be readily updated as new data emerge. A final limitation of this study is that virus contamination in the air, on fomite surfaces, and on hands was assumed to be homogenously distributed. Empirical studies on the distribution of respiratory particles in the air and on fomite surfaces following respiratory events are needed to further refine respiratory transmission pathway modeling.

Future research might include evaluation of SARS-CoV-2 risk associated with packaging in a food supply chain (95) and in outdoor agriculture production and harvest settings; and the impact of population-based interventions, including vaccination, testing, and worker furlough, on SARS-CoV-2 cases and mortality among this essential workforce. This model can also be adapted to other indoor settings (e.g. schools and daycares) to provide evidence-based guidance for SARS-CoV-2 risk mitigation strategies. While this model represented a food manufacturing facility encompassing frozen food processing and fresh cut produce packaging, given additional information on equipment and facility design, this model can readily be adapted to other prepared foods, meat, and poultry processing manufacturing facilities. Taken together, this work advances the evidence-base for existing global $(39,96)$, federal $(37,40)$ and food industry $(97)$ guidelines as effective SARS-CoV-2 infection mitigation strategies to protect essential workers in food manufacturing facilities.

\section{Materials and Methods}

\subsection{Model overview}

Model design of the indoor food manufacturing facility was informed by prior field studies conducted in fresh produce packing facilities along the southern United Sates and northern Mexican border states (98-101). As a representative food manufacturing facility, we also applied information on equipment and facility design from frozen food manufacturers associated with the frozen fruit and vegetable sector. In addition, we leveraged the modeling frameworks of SARS-CoV-2 aerosol transmission in a seafood market in Wuhan, China (79), Middle East Respiratory Virus (MERS) aerosol and droplet transmission in a hospital (102), and fomite-mediated transmission for influenza A virus $(103,104)$. Additional details on model vetting are provided in the SI Appendix.

\subsection{Model structure}

The overall model structure initiates with a single infected worker exposing a single susceptible worker over a work shift lasting up to $8 \mathrm{~h}$ either through coughing (symptomatic) or breathing (asymptomatic) respiratory events. Virus-containing droplets and aerosols generated from these respiratory events then feed into the close contact, aerosol, and fomite-mediated transmission pathways. Please refer to SI Appendix for additional details on the transmission pathways by event. In our model, SARS-CoV-2 infection risk to the susceptible worker resulted from respiration/deposition of particles in the nasal-pharyngeal region (droplet and aerosol); direct spray onto mucous membranes (droplet); and indirect tactile transfers associated with contaminated fomite surface(s) (Figure 1). Exposure to aerosols $(<50 \mu \mathrm{m})$ by the susceptible worker occurred both near (close contact 1-3m) and farther (beyond close contact $>3 \mathrm{~m}$ ) from the infected individual. Exposure to droplets $(50-750 \mu \mathrm{m})$ by the susceptible worker occurred only within close contact distancing. Here, droplet exposures were characterized by the transport properties of the droplets (i.e. 
medRxiv preprint doi: https://doi.org/10.1101/2021.05.14.21257244; this version posted May 18, 2021. The copyright holder for this preprint

(which was not certified by peer review) is the author/funder, who has granted medRxiv a license to display the preprint in perpetuity. It is made available under a CC-BY-NC-ND 4.0 International license .

ballistic gravitational trajectories) and the possible horizontal distance traveled. For instance, with a coughing infected worker, a susceptible worker at $<1 \mathrm{~m}$ distancing would be exposed to the full range of 50 $750 \mu \mathrm{m}$ droplets, whereas distancing of $1-2 \mathrm{~m}$ would result in exposure to $50-100 \mu \mathrm{m}$ droplets (droplets $>100 \mu \mathrm{m}$ having settled to the floor/fomite surface), and distancing of 2-3m would result in exposure to 50$60 \mu \mathrm{m}$ droplets (droplets $>60-100 \mu \mathrm{m}$ having settled to the floor/fomite surface). In addition to these droplet exposures, when in close contact, a susceptible worker would also be exposed to aerosol particles $(<50$ $\mu \mathrm{m}$ ), as coughing events produce both aerosol and droplet particles simultaneously. Viral contamination of a fomite surface occurred through respiratory particles falling from the air, either by the terminal settling velocity of aerosols or gravitational ballistic trajectory of droplets, onto a $0.5 \mathrm{~m}$ by $0.5 \mathrm{~m}$ stainless steel surface within $1 \mathrm{~m}$ of the susceptible worker. Of the total respiratory particle fallout from the air, we assumed only a proportion of this total would land and contaminate the fomite surface (fomite surface area/crosssectional facility area). Fomite-mediated transmission involved tactile contact between the susceptible worker's fingers and palms (of both hands) and the fomite surface (accounting for surface area of the hand relative to the fomite surface); virus transfer from fomite to hands; followed by virus transfer from fingertips to facial mucous membranes (accounting for the surface area of the fingers relative to that of the hands). SARS-CoV-2 infection risk to the susceptible worker was calculated by incorporating the dose from each individual transmission pathway and applying an exponential dose-response model based on data from SARS-CoV and murine hepatitis virus infection in mice $(105,106)$. As there is currently no SARS-CoV-2 dose-response model, consistent with other SARS-CoV-2 QMRA models (18, 50, 60, 61), we applied this SARS-CoV dose-response given the high degree of comparability between SARS-CoV and SARS-CoV-2 (genetic and amino acid homology, transmission pathways, etc.) (73). Infection control measures were implemented to target one or more of the SARS-CoV-2 transmission pathways (droplet, aerosol, and fomitemediated). For instance, mask use by the infected worker aimed to interrupt the shedding of virus-laden droplet and aerosol particles into the air and on the fomite surface and to protect the susceptible worker. Similarly, handwashing and surface disinfection disrupted the indirect tactile transfer of virus to the susceptible worker's mucous membranes.

The two model outcomes included: 1) the individual and cumulative SARS-CoV-2 infection risks from close contact (droplet and aerosols at 1, 2, 3m), aerosol $(<50 \mu \mathrm{m})$, and fomite-mediated (droplet and aerosol fallout) exposures to a susceptible worker following an up to 8h-shift with an infected worker in an indoor food manufacturing facility; and 2) the relative reduction in SARS-CoV-2 infection risk attributed to commonly-used infection control interventions (physical distancing, mask use, air change rates, surface disinfection, hand hygiene). The model was developed in $\mathrm{R}$ (version 4.0.3; R Development Core Team; Vienna, Austria) using the mc2d package for Monte Carlo simulations and sensitivity analyses (107). For each simulation, 10,000 iterations were run using model parameters selected from defined probability distributions or assigned values (SI Appendix, Table S1). Sensitivity analyses conducted on the simulation number demonstrated the risk estimates stabilized after 1,000 iterations, ensuring 10,000 iterations were more than sufficient. Please refer to SI Appendix for additional details on the transmission pathways by event.

\subsection{Data sources}

Model parameters derived from the peer-reviewed literature were grouped into five categories and are summarized in SI Appendix, Table S1. These included: (i) facility specifications; (ii) viral shedding through cough or breathing events; (iii) fomite-mediated transmission parameters; (iv) dose-response parameters for SARS-CoV-2 infection risk; and (v) risk mitigation interventions (physical distancing, ventilation, mask use, surface disinfection, hand hygiene). The indoor food manufacturing facility simulated in this model was a single-story building $(10 \mathrm{~m} \times 10 \mathrm{~m} \times 10 \mathrm{~m})$, representing a total volume of 1000 cubic meters with an internal temperature of $70^{\circ} \mathrm{F}$ and relative humidity of $40-65 \%$, which is similar to conditions in many facilities in the industry (personal communication with Dr. Sanjay Gummalla, American Frozen Food Industry).

\subsection{Model validation and calibration}

Following model development, validation was conducted to ensure the model structure and risk estimates aligned with the published literature, our evolving understanding of SARS-CoV-2 biology and environmental behavior, and that risk estimates were of an appropriate order of magnitude relative to documented SARSCoV-2 outbreaks. This involved elicitations of opinions from food processing experts related to the structure of the model and relevant model inputs (e.g. facility ventilation, standard operating procedures for masks, 
medRxiv preprint doi: https://doi.org/10.1101/2021.05.14.21257244; this version posted May 18, 2021. The copyright holder for this preprint

(which was not certified by peer review) is the author/funder, who has granted medRxiv a license to display the preprint in perpetuity.

It is made available under a CC-BY-NC-ND 4.0 International license .

types of surface disinfection products and their frequency of use, etc.); additional details are in SI Appendix. Through a systematic review of all published (on or prior to December 2020) SARS-CoV-2 outbreaks with confirmed-positive index and secondary cases, we compared model risk estimates to those derived from real life situations such as SARS-CoV-2 household transmission and recreational or work-based activities with well-defined exposure times and distances. We calibrated our model to the risk for a $1 \mathrm{~h}$, close contact $(1 \mathrm{~m})$ exposure to that of approximately $38 \%(108,109)$, which represents the attack rate from two wellcharacterized, $1 \mathrm{~h}$ close contact $(1 \mathrm{~m})$ exposures. Specifically, this calibration involved adjusting select parameters (e.g. salivary viral titer, coughing frequency, dose-response infectivity), while remaining within the range of parameter values derived from the literature. This calibration was corroborated by additional elicitation of opinions from infectious disease clinicians treating COVID-19 patients in metro-Atlanta.

\subsection{Aerosol transmission modeling}

For aerosol transmission, we leveraged the SARS-CoV-2 air transport model proposed by Zhang et al. (79), with modifications as described below and in SI Appendix. Briefly, aerosolized particles were assumed to be homogenously distributed throughout the facility, such that aerosol exposure by the susceptible worker was uniform throughout the entire indoor facility. Viral particles were removed through viral decay, based on a temperature- and humidity-specific viral decay rate, $\lambda_{v}(1 / \mathrm{s})$, and removal by ventilation, $Q\left(\mathrm{~m}^{3} / \mathrm{s}\right)$ converted from air changes per hour ( $\mathrm{ACH})$. The baseline model assumed negligible ventilation ( $\mathrm{ACH} 0.1)$. The total loss of virus-containing room air volume was calculated as:

$V_{\text {loss }}=Q+\left(\lambda_{v} \cdot f_{V}\right)$

where $f_{v}$ represented the facility volume $\left(m^{3}\right)$.

The concentration of infectious SARS-CoV-2 particles $\left(\mathrm{PFU} / \mathrm{m}^{3}\right)$ at time $t$ remaining in the air, $\left(\mathrm{C}_{\mathrm{t}}\right)$, was calculated by:

$C_{t}=\frac{1}{V_{\text {loss }}}\left(1-\exp \left(\frac{-V_{\text {loss }} \cdot \Delta t}{f_{V}}\right)\right) \cdot \sigma$

$C_{t=0}=0$

where, $\sigma$ was the viral shedding rate (PFU/s) from an infected worker and $\Delta t$ the time change $(1 / \mathrm{s})$ from the prior one-hour time step. The virus-laden particles that remained in the air from the prior time-step (based on change in time, $\Delta t), \mathrm{C}_{\mathrm{t}, \mathrm{carr}},\left(\mathrm{PFU} / \mathrm{m}^{3}\right)$ were included in the calculation of the total viral concentration, $C_{t, t o t a l},\left(\mathrm{PFU} / \mathrm{m}^{3}\right)$ at time t:

$C_{t, \text { carry }}=C_{t-\Delta t} \cdot \exp \left(\frac{-V_{\text {loss }} \cdot \Delta t}{f_{V}}\right)$

$C_{t, \text { total }}=C_{t, \text { carry }}+C_{t}$

The amount of virus that fell from the air, Fallt,a (PFU), at each time-step was determined by the particle size-dependent terminal settling velocity, $(\mathrm{m} / \mathrm{s})\left(v_{t s}\right)$, the facility surface area $\left(\mathrm{m}^{2}\right)\left(f_{a}\right)$, and $\Delta t$ as follows:

Fall $_{t, a}=C_{t, \text { total }} \cdot f_{a} \cdot v_{t s} \cdot \Delta t$

Viral loss due to the aerosol terminal settling velocities and viral decay at $1 \mathrm{~h}$ intervals was nominal, resulting in accumulation of virus-laden aerosol particles in the air over time.

\subsection{Close contact transmission modeling}

Close contact transmission represented exposure of the susceptible worker within 1,2 , and $3 \mathrm{~m}$ of the infected worker to droplets (direct spray, respiration) and aerosols (respiration) that deposited into the nasal-pharyngeal region or entered the upper airways. As larger particles $(>50 \mu \mathrm{m})$ settle out of the air at faster rates than aerosols $(<50 \mu \mathrm{m})$, for close contact transmission we assumed that all droplets $(>50-750$ $\mu \mathrm{m}$ ) would fall from the air over the course of each one-hour time-step. Therefore, there was no carry-over or accumulation of virus in the air associated with these large droplets between time-steps. To reflect these droplet particle dynamics, particle probability estimates (denoted $p p$ ) derived from modeling work by Wei et 
medRxiv preprint doi: https://doi.org/10.1101/2021.05.14.21257244; this version posted May 18, 2021. The copyright holder for this preprint (which was not certified by peer review) is the author/funder, who has granted medRxiv a license to display the preprint in perpetuity. It is made available under a CC-BY-NC-ND 4.0 International license .

al., (110) were used to generate the proportion of droplets that are capable of reaching $1-3 \mathrm{~m}$ distances as follows:

$C_{t}=\left[\frac{1}{V_{\text {loss }}}\left(1-\exp \left(\frac{-V_{\text {loss }} \cdot \Delta t}{f_{V}}\right)\right) \cdot \sigma\right] \cdot p p$

Here, $p p$ represented the probability that a droplet would reach 1-3m. This droplet-mediated viral exposure was added to the aerosol viral exposure calculated in section 2.5 to generate the close contact transmission exposures (droplets and aerosols) for 1-3m distances. The inverse of $p p$, ppfall, was used to calculate the viral concentration $\left(\mathrm{PFU} / \mathrm{m}^{3}\right)$ fallout from the air and available to contaminate the fomite surface (Fall $\left.\mathrm{t}\right)$ :

Fall $_{t}=C_{t} \cdot p p f a l l$,

where, $C_{t}$ is the viral concentration $\left(\mathrm{PFU} / \mathrm{m}^{3}\right)$ in the air at time $\mathrm{t}$.

\subsection{Fomite-mediated transmission modeling}

Fomite-mediated transmission was calculated using the droplet and aerosol fallout, Fall $t_{t, a}(P F U)$ and Fallt $\left(\mathrm{PFU} / \mathrm{m}^{3}\right)$ and the resulting viral contamination on the fomite surface, $\mathrm{F}_{\mathrm{t}, \mathrm{a}}$ and $\mathrm{F}_{\mathrm{t}, \mathrm{ccd}}(\mathrm{PFU})$, at time $\mathrm{t}$ :

Fallout from aerosols:

$F_{t, a}=F_{t-1}+\frac{\text { Fall }_{t, a} \cdot H_{s a}}{f_{a} \cdot \lambda_{v, \text { fomite }}} \cdot\left[1-\exp \left(-\lambda_{v, \text { fomite }} \cdot t\right)\right]$

Fallout from close contact droplets:

$F_{t, c c d}=F_{t-1}+\frac{F a l l_{t} \cdot f_{V} \cdot H_{s a}}{f_{a} \cdot \lambda_{v, \text { fomite }}} \cdot\left[1-\exp \left(-\lambda_{v, \text { fomite }} \cdot t\right)\right]$

$F_{t=0}=0$

where $f_{v}$ was the volume of the facility $\left(\mathrm{m}^{3}\right), \mathrm{H}_{\mathrm{sa}}$ was the surface area of the susceptible worker's hand that touched the fomite surface $\left(\mathrm{m}^{2}\right)$, $\mathrm{f}_{\mathrm{a}}$ was the cross-sectional area of the facility $\left(\mathrm{m}^{2}\right)$, and $\lambda_{v \text {,fomite }}$ was the viral decay of SARS-CoV-2 on the fomite surface. The concentration of SARS-CoV-2 transferred to a hand, $\mathrm{C}_{\text {hand }}(\mathrm{PFU} / \mathrm{h})$, following a tactile event at time $\mathrm{t}$ was calculated using an approach previously applied to influenza A virus exposure (103):

$C_{\text {hand }}(t)=\frac{H_{\text {surface }} \cdot F_{t} \cdot F_{12}}{\lambda_{v, \text { hand }}} \cdot\left[1-\exp \left(-\lambda_{v, \text { hand }} \cdot t\right)\right]$

where $\mathrm{H}_{\text {surface }}$ was the frequency of contacts between the hand and fomite per minute (contacts/min), $\mathrm{F}_{\mathrm{t}}$ was the viral concentration on the fomite (PFU) at time $t, F_{12}$ was the proportion of virus transferred from fomite to hand, and $\lambda_{\mathrm{v} \text {,hand }}$ was the viral decay of SARS-CoV-2 on the hand. The concentration of SARS-CoV-2 on the hand and fallout from close contact droplets both assume first-order loss of virus infectivity.

\subsection{Risk assessment}

Individual and cumulative SARS-CoV-2 infection risks for all three transmission pathways (droplet, aerosol, and fomite-mediated) were estimated for the susceptible worker following an 8h-shift based on exposure to each pathway.

Aerosol and droplet doses were calculated based on the infectious virus concentration in the air $\left(\mathrm{C}_{\mathrm{t}}\right)$, lung deposition fraction $\left(L_{d e p}\right)$, inhalation rate $\left(I_{R}\right)$, and exposure duration $\left(E_{t}\right)$ :

$D_{\text {air }}(t)=C_{t} \cdot L_{\text {dep }} \cdot I_{R} \cdot E_{t}$ 
medRxiv preprint doi: https://doi.org/10.1101/2021.05.14.21257244; this version posted May 18, 2021. The copyright holder for this preprint

(which was not certified by peer review) is the author/funder, who has granted medRxiv a license to display the preprint in perpetuity.

It is made available under a CC-BY-NC-ND 4.0 International license .

The fomite-mediated dose was calculated from the viral contamination on the hand $\left(\mathrm{C}_{\text {hand }}\right)$ at time $t$, the frequency of hand-to-face contacts $\left(\mathrm{H}_{\text {face }}\right)$, the surface area ratio of fingers $\left(\mathrm{F}_{\mathrm{sa}}\right)$ to hand $\left(\mathrm{H}_{\mathrm{sa}}\right)$, the fraction of pathogens transferred from hand-to-face $\left(F_{23}\right)$, and the exposure duration $(h)$ :

$D_{\text {fomite }}(t)=\frac{H_{\text {face }} \cdot F_{s a} \cdot C_{\text {hand }}(t) \cdot F_{23} \cdot t}{H_{s a}}$

The probability of infection for a given dose based on these individual and combined transmission pathway exposures was estimated using an exponential dose-response model ( $\left.\mathrm{k}_{\text {risk }}\right)$. This model was based on the pooled data from studies of SARS-CoV and murine hepatitis virus infection in mice by intranasal administration $(105,106)$ :

$R(t)=1-\exp \left[-k_{\text {risk }} \cdot D(t)\right]$

$R_{\text {combined }}(t)=1-\exp \left[-k_{\text {risk }} \cdot\left(D_{\text {aerosol }}(t)+D_{\text {droplet }}(t)+D_{\text {fomite }}(t)\right)\right]$

For the combined risk estimate, doses from the individual transmission pathways were assumed to be independent.

\subsection{Stochastic sensitivity analysis}

Spearman rank correlation coefficients were used to identify the most influential parameters in the model by ranking the correlation between risk estimates $(8 \mathrm{~h})$ and parameter values using the tornado diagram plotting function within the mc2d package in $R$. To examine the contribution of each parameter to the propagation and overall variability within the model, we applied the built-in "mcratio" function (111) in the mc2d R-package.

\subsection{Risk mitigation intervention testing}

Risk mitigation interventions were selected based on international (EU-OSHA)- and domestic (OSHA, FDA)-recommended guidance and industry practices (according to survey results from food manufacturing facility managers) for worker safety (40) and COVID-19 prevention (37). Interventions included physical distancing (1-3m), concordant universal mask use (surgical, cloth, double masking, N95), improved air changes per hour (ACH 2-8), surface disinfection (3-4 $\log _{10}$ virus removal) (112), and hand hygiene (handwashing [2 $\log _{10}$ virus removal (113)], alcohol-based hand sanitizer [ $3 \log _{10}$ virus removal], and glove use $[100 \%$ virus removal]). Due to the variability in virus removal efficacies of surface disinfectants across products and in hand hygiene practices, we set these efficacies as point values in the model. Surface disinfection was simulated once, twice, four times and hourly per $8 \mathrm{~h}$-shift, and hand hygiene was simulated hourly (i.e. handwashing, hand sanitizer, glove use) (personal communications with Dr. Sanjay Gummalla, American Frozen Food Industry). All risk mitigation strategies were assumed to be implemented with 100\% compliance and in the manner specified. Parameters associated with the interventions (see Supplementary Materials) were based on controlled laboratory studies.

\section{Acknowledgments}

This work was partially supported by the National Institutes of Health T32 grant (J.S.S., grant 2T32ES012870-16), the National Institute of Food and Agriculture at the U.S. Department of Agriculture (J.S.L. 2018-07410; J.S.S., grant 2020-67034-31728), the National Institute General Medical Sciences (B.A.L R01 GM124280), the National Science Foundation (B.A.L. 2032084), the National Institute Of Allergy And Infectious Diseases of the National Institutes of Health (E.T.S., T32Al138952), and Emory University and the Infectious Disease Across Scales Training Program (IDASTP) (E.T.S). The contents of this paper are solely the responsibility of the authors and do not necessarily represent the official views of the National Institutes of Health, or the U.S. Department of Agriculture.

The authors would like to thank Dr. Sanjay Gummalla (American Frozen Food Industry), Dr. Lory Reveil (American Frozen Food Industry), and Dr. Max Teplitski (Produce Marketing Association) for their valuable 
medRxiv preprint doi: https://doi.org/10.1101/2021.05.14.21257244; this version posted May 18, 2021. The copyright holder for this preprint

(which was not certified by peer review) is the author/funder, who has granted medRxiv a license to display the preprint in perpetuity.

It is made available under a CC-BY-NC-ND 4.0 International license .

time and input as food production and processing experts and for conducting surveys of facilities. We also thank Carol Liu and the infectious disease physicians for their participation in our model calibration efforts.

An open access license has been selected

\section{References}

1. Waltenburg MA, et al. (2020) Update: COVID-19 Among Workers in Meat and Poultry Processing Facilities - United States, April-May 2020. MMWR Morb Mortal Wkly Rep 69(27):887-892.

2. Dyal JW, et al. (2020) COVID-19 Among Workers in Meat and Poultry Processing Facilities - 19 States, April 2020. MMWR Morb Mortal Wkly Rep 69(18).

3. Chen Y, et al. (2021) Excess mortality associated with the COVID-19 pandemic among Californians 18-65 years of age, by occupational sector and occupation: March through October 2020. medRxiv.

4. Rubenstein BL, et al. (2020) Factors That Might Affect SARS-CoV-2 Transmission Among Foreign-Born and U.S.-Born Poultry Facility Workers - Maryland, May 2020. MMWR Morb Mortal Wkly Rep 69(50):1906-1910.

5. Cable J, Jaykus LA, Hoelzer K, Newton J, \& Torero M (2021) The impact of COVID-19 on food systems, safety, and security-a symposium report. Ann N Y Acad Sci 1484(1):3-8.

6. Herstein JJ, et al. (2021) Characteristics of SARS-CoV-2 Transmission among Meat Processing Workers in Nebraska, USA, and Effectiveness of Risk Mitigation Measures. Emerg Infect Dis 27(4):1032-1038.

7. Duguid JP (1945) The numbers and the sites of origin of the droplets expelled during expiratory activities. Edinburgh medical journal 52:385-401.

8. Steinberg J, et al. (2020) COVID-19 Outbreak Among Employees at a Meat Processing Facility South Dakota, March-April 2020. MMWR Morb Mortal Wkly Rep 69(31):1015-1019.

9. Pöhlker M, et al. (2021) Respiratory aerosols and droplets in the transmission of infectious diseases. ed Chemistry MPIf (arxiv.org).

10. Prather KA, et al. (2020) Airborne transmission of SARS-CoV-2. Science 370(6514):303.

11. Bourouiba L (2020) Turbulent Gas Clouds and Respiratory Pathogen Emissions: Potential Implications for Reducing Transmission of COVID-19. JAMA 323(18):1837-1838.

12. Morawska L, et al. (2009) Size distribution and sites of origin of droplets expelled from the human respiratory tract during expiratory activities. Journal of Aerosol Science 40(3):256-269.

13. Stadnytskyi V, Bax CE, Bax A, \& Anfinrud P (2020) The airborne lifetime of small speech droplets and their potential importance in SARS-CoV-2 transmission. Proc Natl Acad Sci U S A 117(22):11875-11877.

14. Shen Y, et al. (2020) Community Outbreak Investigation of SARS-CoV-2 Transmission Among Bus Riders in Eastern China. JAMA Intern Med 180(12):1665-1671.

15. Liu Y, et al. (2020) Aerodynamic analysis of SARS-CoV-2 in two Wuhan hospitals. Nature 582(7813):557-560.

16. Miller SL, et al. (2020) Transmission of SARS-CoV-2 by inhalation of respiratory aerosol in the Skagit Valley Chorale superspreading event. Indoor Air.

17. Azimi P, Keshavarz Z, Cedeno Laurent JG, Stephens B, \& Allen JG (2021) Mechanistic transmission modeling of COVID-19 on the Diamond Princess cruise ship demonstrates the importance of aerosol transmission. Proc Natl Acad Sci U S A 118(8).

18. Jones RM (2020) Relative contributions of transmission routes for COVID-19 among healthcare personnel providing patient care. J Occup Environ Hyg 17(9):408-415.

19. Brlek A, Vidovic S, Vuzem S, Turk K, \& Simonovic Z (2020) Possible indirect transmission of COVID-19 at a squash court, Slovenia, March 2020: case report. Epidemiol Infect 148:e120.

20. Chia PY, et al. (2020) Detection of air and surface contamination by SARS-CoV-2 in hospital rooms of infected patients. Nat Commun 11(1):2800.

21. Moore G, et al. (2021) Detection of SARS-CoV-2 within the healthcare environment: a multicentre study conducted during the first wave of the COVID-19 outbreak in England. $J$ Hosp Infect 108:189-196. 
medRxiv preprint doi: https://doi.org/10.1101/2021.05.14.21257244; this version posted May 18, 2021. The copyright holder for this preprint

(which was not certified by peer review) is the author/funder, who has granted medRxiv a license to display the preprint in perpetuity.

It is made available under a CC-BY-NC-ND 4.0 International license .

22. van Doremalen N, et al. (2020) Aerosol and Surface Stability of SARS-CoV-2 as Compared with SARS-CoV-1. N Engl J Med 382(16):1564-1567.

23. Fears AC, et al. (2020) Persistence of Severe Acute Respiratory Syndrome Coronavirus 2 in Aerosol Suspensions. Emerg Infect Dis 26(9).

24. He X, et al. (2020) Temporal dynamics in viral shedding and transmissibility of COVID-19. Nat Med 26(5):672-675.

25. Wolfel R, et al. (2020) Virological assessment of hospitalized patients with COVID-2019. Nature 581(7809):465-469.

26. Boone SA \& Gerba CP (2007) Significance of fomites in the spread of respiratory and enteric viral disease. Appl Environ Microbiol 73(6):1687-1696.

27. Kraay ANM, et al. (2018) Fomite-mediated transmission as a sufficient pathway: a comparative analysis across three viral pathogens. BMC Infect Dis 18(1):540.

28. Xiao S, Li Y, Wong TW, \& Hui DSC (2017) Role of fomites in SARS transmission during the largest hospital outbreak in Hong Kong. PLoS One 12(7):e0181558.

29. Xie C, et al. (2020) The evidence of indirect transmission of SARS-CoV-2 reported in Guangzhou, China. BMC Public Health 20(1):1202.

30. Yuan J, et al. (2020) Sewage as a Possible Transmission Vehicle During a Coronavirus Disease 2019 Outbreak in a Densely populated Community: Guangzhou, China, April 2020. Clinical Infectious Diseases.

31. Jiang FC, et al. (2020) Detection of Severe Acute Respiratory Syndrome Coronavirus 2 RNA on Surfaces in Quarantine Rooms. Emerg Infect Dis 26(9).

32. Bedrosian N, et al. (2020) A Systematic Review of Surface Contamination, Stability, and Disinfection Data on SARS-CoV-2 (Through July 10, 2020). Environ Sci Technol.

33. Harvey AP, et al. (2020) Longitudinal monitoring of SARS-CoV-2 RNA on high-touch surfaces in a community setting. medRxiv.

34. Paton S, et al. (2021) Persistence of SARS-CoV-2 virus and viral RNA in relation to surface type and contamination concentration. Appl Environ Microbiol.

35. Goldman E (2020) Exaggerated risk of transmission of COVID-19 by fomites. Lancet Infect Dis 20(8):892-893.

36. Lewis D (2021) COVID-19 rarely spreads through surfaces. So why are we still deep cleaning? Nature 590(7844):26-28.

37. FDA \& OSHA (2020) Employee Health and Food Safety Checklist for Human and Animal Food Operations During the COVID-19 Pandemic (FDA, fda.gov), U.S. Food \& Drug Administration (Administration USFaDAaOSaH).

38. OSHA (2021) Protecting Workers: Guidance on Mitigating and Preventing the Spread of COVID19 in the Workplace, (Labor USDo).

39. Cockburn W (2020) COVID-19: Back to the workplace, adapting workplaces and protecting workers, ((EU-OSHA) EAfSaHaW).

40. United States Food and Drug Administration (2013) Food Safety Modernization Act Proposed Rule for Produce Safety, Standards for the Growing, Harvesting, Packing, and Holding of Produce for Human Consumption, (Corrected version). in 21 CFR Parts 16 and 112, ed U.S. Food and Drug Administration.

41. Kucharski AJ, et al. (2020) Effectiveness of isolation, testing, contact tracing, and physical distancing on reducing transmission of SARS-CoV-2 in different settings: a mathematical modelling study. The Lancet Infectious Diseases 20(10):1151-1160.

42. Chu DK, et al. (2020) Physical distancing, face masks, and eye protection to prevent person-toperson transmission of SARS-CoV-2 and COVID-19: a systematic review and meta-analysis. The Lancet 395(10242):1973-1987.

43. Asadi S, et al. (2020) Efficacy of masks and face coverings in controlling outward aerosol particle emission from expiratory activities. Scientific Reports 10(1):15665.

44. Ueki H, et al. (2020) Effectiveness of Face Masks in Preventing Airborne Transmission of SARSCoV-2. mSphere 5(5):e00637-00620.

45. Fischer EP, et al. (2020) Low-cost measurement of face mask efficacy for filtering expelled droplets during speech. Sci Adv6(36). 
medRxiv preprint doi: https://doi.org/10.1101/2021.05.14.21257244; this version posted May 18, 2021. The copyright holder for this preprint

(which was not certified by peer review) is the author/funder, who has granted medRxiv a license to display the preprint in perpetuity.

It is made available under a CC-BY-NC-ND 4.0 International license .

46. Lindsley WG, Blachere FM, Law BF, Beezhold DH, \& Noti JD (2020) Efficacy of face masks, neck gaiters and face shields for reducing the expulsion of simulated cough-generated aerosols. Aerosol Science and Technology:1-9.

47. Pan J, Harb C, Leng W, \& Marr LC (2020) Inward and outward effectiveness of cloth masks, a surgical mask, and a face shield. medRxiv:2020.2011.2018.20233353.

48. Chan $\mathrm{KH}$, et al. (2020) Factors affecting stability and infectivity of SARS-CoV-2. Journal of Hospital Infection 106(2):226-231.

49. Chin AWH, et al. (2020) Stability of SARS-CoV-2 in different environmental conditions. Lancet Microbe 1(1):e10.

50. Wilson AM, Weir MH, Bloomfield SF, Scott EA, \& Reynolds KA (2020) Modeling COVID-19 infection risks for a single hand-to-fomite scenario and potential risk reductions offered by surface disinfection. Am J Infect Control.

51. Mokhtari A \& Jaykus LA (2009) Quantitative exposure model for the transmission of norovirus in retail food preparation. International Journal of Food Microbiology 133(1-2):38-47.

52. Bouwknegt M, et al. (2015) Quantitative farm-to-fork risk assessment model for norovirus and hepatitis A virus in European leafy green vegetable and berry fruit supply chains. International Journal of Food Microbiology 198:50-58.

53. Jacxsens L, et al. (2017) Quantitative farm-to-fork human norovirus exposure assessment of individually quick frozen raspberries and raspberry puree. Int J Food Microbiol 242:87-97.

54. Barker SF (2014) Risk of norovirus gastroenteritis from consumption of vegetables irrigated with highly treated municipal wastewater--evaluation of methods to estimate sewage quality. Risk Anal 34(5):803-817.

55. Duret S, et al. (2017) Quantitative Risk Assessment of Norovirus Transmission in Food Establishments: Evaluating the Impact of Intervention Strategies and Food Employee Behavior on the Risk Associated with Norovirus in Foods. Risk Anal 37(11):2080-2106.

56. King M-F, et al. (2020) Modelling the risk of SARS-CoV-2 infection through PPE doffing in a hospital environment. medRxiv:2020.2009.2020.20197368.

57. Wilson AM, et al. (2020) COVID-19 and use of non-traditional masks: how do various materials compare in reducing the risk of infection for mask wearers? J Hosp Infect 105(4):640-642.

58. Dada AC \& Gyawali P (2021) Quantitative microbial risk assessment (QMRA) of occupational exposure to SARS-CoV-2 in wastewater treatment plants. Science of The Total Environment 763:142989.

59. Zaneti RN, et al. (2021) Quantitative microbial risk assessment of SARS-CoV-2 for workers in wastewater treatment plants. Science of The Total Environment 754:142163.

60. Pitol AK \& Julian TR (2021) Community Transmission of SARS-CoV-2 by Surfaces: Risks and Risk Reduction Strategies. Environmental Science \& Technology Letters.

61. Harvey AP, et al. (2021) Longitudinal Monitoring of SARS-CoV-2 RNA on High-Touch Surfaces in a Community Setting. Environmental Science \& Technology Letters 8(2):168-175.

62. He W, Yi GY, \& Zhu Y (2020) Estimation of the basic reproduction number, average incubation time, asymptomatic infection rate, and case fatality rate for COVID-19: Meta-analysis and sensitivity analysis. J Med Virol 92(11):2543-2550.

63. Mizumoto K \& Chowell G (2020) Transmission potential of the novel coronavirus (COVID-19) onboard the diamond Princess Cruises Ship, 2020. Infect Dis Model 5:264-270.

64. Zhang S, et al. (2020) Estimation of the reproductive number of novel coronavirus (COVID-19) and the probable outbreak size on the Diamond Princess cruise ship: A data-driven analysis. Int $J$ Infect Dis 93:201-204.

65. Papineni RS \& Rosenthal FS (1997) The size distribution of droplets in the exhaled breath of healthy human subjects. Journal of Aerosol Medicine: Deposition, Clearance, and Effects in the Lung 10(2):105-116.

66. Nicas M, Nazaroff WW, \& Hubbard A (2005) Toward understanding the risk of secondary airborne infection: emission of respirable pathogens. J Occup Environ Hyg 2(3):143-154.

67. Yan J, et al. (2018) Infectious virus in exhaled breath of symptomatic seasonal influenza cases from a college community. Proceedings of the National Academy of Sciences 115(5):1081.

68. Milton DK, Fabian MP, Cowling BJ, Grantham ML, \& McDevitt JJ (2013) Influenza Virus Aerosols in Human Exhaled Breath: Particle Size, Culturability, and Effect of Surgical Masks. PLOS Pathogens 9(3):e1003205. 
medRxiv preprint doi: https://doi.org/10.1101/2021.05.14.21257244; this version posted May 18, 2021. The copyright holder for this preprint

(which was not certified by peer review) is the author/funder, who has granted medRxiv a license to display the preprint in perpetuity.

It is made available under a CC-BY-NC-ND 4.0 International license .

69. Leung NHL, et al. (2020) Respiratory virus shedding in exhaled breath and efficacy of face masks. Nature Medicine 26(5):676-680.

70. Lindsley WG, et al. (2016) Viable influenza A virus in airborne particles expelled during coughs versus exhalations. Influenza Other Respir Viruses 10(5):404-413.

71. Wang Y, Xu G, \& Huang Y-W (2020) Modeling the load of SARS-CoV-2 virus in human expelled particles during coughing and speaking. PLOS ONE 15(10):e0241539.

72. World Health O (2016) Quantitative Microbial Risk Assessment: Application for Water Safety Management (World Health Organization, Geneva).

73. Hu B, Guo H, Zhou P, \& Shi Z-L (2021) Characteristics of SARS-CoV-2 and COVID-19. Nature Reviews Microbiology 19(3):141-154.

74. Ong SWX, et al. (2020) Air, Surface Environmental, and Personal Protective Equipment Contamination by Severe Acute Respiratory Syndrome Coronavirus 2 (SARS-CoV-2) From a Symptomatic Patient. JAMA 323(16):1610-1612.

75. Bourouiba L, Dehandschoewercker E, \& Bush JWM (2014) Violent expiratory events: On coughing and sneezing. Journal of Fluid Mechanics 745:537-563.

76. Chen W, Zhang N, Wei J, Yen H-L, \& Li Y (2020) Short-range airborne route dominates exposure of respiratory infection during close contact. Building and Environment 176:106859.

77. Doung-Ngern P, et al. (2020) Case-Control Study of Use of Personal Protective Measures and Risk for SARS-CoV 2 Infection, Thailand. Emerg Infect Dis 26(11):2607-2616.

78. Somsen GA, van Rijn C, Kooij S, Bem RA, \& Bonn D (2020) Small droplet aerosols in poorly ventilated spaces and SARS-CoV-2 transmission. Lancet Respir Med 8(7):658-659.

79. Zhang X, Ji Z, Yue Y, Liu H, \& Wang J (2020) Infection Risk Assessment of COVID-19 through Aerosol Transmission: a Case Study of South China Seafood Market. Environmental Science and Technology.

80. Brooks JT, et al. (2021) Maximizing Fit for Cloth and Medical Procedure Masks to Improve Performance and Reduce SARS-CoV-2 Transmission and Exposure, 2021. MMWR Morb Mortal Wkly Rep 70(7):254-257.

81. Kennedy M, Lee SJ, \& Epstein M (2021) Modeling aerosol transmission of SARS-CoV-2 in multiroom facility. J Loss Prev Process Ind 69:104336.

82. Curtius J, Granzin M, \& Schrod J (2021) Testing mobile air purifiers in a school classroom: Reducing the airborne transmission risk for SARS-CoV-2. Aerosol Science and Technology 55(5):586-599.

83. Li Y, et al. (2007) Role of ventilation in airborne transmission of infectious agents in the built environment - a multidisciplinary systematic review. Indoor Air 17(1):2-18.

84. Gunther T, et al. (2020) SARS-CoV-2 outbreak investigation in a German meat processing plant. EMBO Mol Med 12(12):e13296.

85. Lu J, et al. (2020) COVID-19 Outbreak Associated with Air Conditioning in Restaurant, Guangzhou, China, 2020. Emerg Infect Dis 26(7):1628-1631.

86. Park SY, et al. (2020) Coronavirus Disease Outbreak in Call Center, South Korea. Emerg Infect Dis 26(8):1666-1670.

87. Chaudhry SK \& Elumalai SP (2020) The influence of school bus ventilation scenarios over incabin PM number concentration and air exchange rates. Atmospheric Pollution Research 11(8):1396-1407.

88. Morawska L, et al. (2020) How can airborne transmission of COVID-19 indoors be minimised? Environ Int 142:105832.

89. Honein MA, et al. (2020) Summary of Guidance for Public Health Strategies to Address High Levels of Community Transmission of SARS-CoV-2 and Related Deaths, December 2020. MMWR Morb Mortal Wkly Rep 69(49):1860-1867.

90. Buising KL, et al. (2021) Use of portable air cleaners to reduce aerosol transmission on a hospital COVID-19 ward. medRxiv:2021.2003.2029.21254590.

91. Buonanno M, Welch D, Shuryak I, \& Brenner DJ (2020) Far-UVC light (222 nm) efficiently and safely inactivates airborne human coronaviruses. Scientific Reports 10(1):10285.

92. FDA (2015) Food Safety Modernization Act final rule on produce safety, standards for the growing, harvesting, packing, and holding of produce for human consumption. 21 CFR Parts 16 and 112, vol. FDA-2011-N-0921. 
medRxiv preprint doi: https://doi.org/10.1101/2021.05.14.21257244; this version posted May 18, 2021. The copyright holder for this preprint

(which was not certified by peer review) is the author/funder, who has granted medRxiv a license to display the preprint in perpetuity.

It is made available under a CC-BY-NC-ND 4.0 International license .

93. FAO (2012) Guidelines on the Application of General Principles of Food Hygiene to the Control of Viruses in Food. pp 1-13.

94. Popa A, et al. (2020) Mutational dynamics and transmission properties of SARS-CoV-2 superspreading events in Austria. bioRxiv:2020.2007.2015.204339.

95. Han J, Zhang X, He S, \& Jia P (2021) Can the coronavirus disease be transmitted from food? A review of evidence, risks, policies and knowledge gaps. Environmental Chemistry Letters 19(1):516.

96. WHO \& FAO (2020) COVID-19 and Food Safety: Guidance for competent authorities responsible for national food safety control systems: Interim guidance.

97. PMA (2020) Preventing the Spread of COVID-19 in Food Facilities. (Produce Marketing Association, pma.com/topics/emergency-management).

98. Newman KL, et al. (2017) Microbial Load of Fresh Produce and Paired Equipment Surfaces in Packing Facilities Near the U.S. and Mexico Border. J Food Prot 80(4):582-589.

99. Ailes EC, et al. (2008) Microbial concentrations on fresh produce are affected by postharvest processing, importation, and season. J Food Prot 71(12):2389-2397.

100. Johnston LM, et al. (2005) A field study of the microbiological quality of fresh produce. J Food Prot 68(9):1840-1847.

101. Johnston LM, et al. (2006) A field study of the microbiological quality of fresh produce of domestic and Mexican origin. Int J Food Microbiol 112(2):83-95.

102. Adhikari U, et al. (2019) A Case Study Evaluating the Risk of Infection from Middle Eastern Respiratory Syndrome Coronavirus (MERS-CoV) in a Hospital Setting Through Bioaerosols. Risk Analysis 39(12):2608-2624.

103. Nicas M \& Best D (2008) A study quantifying the hand-to-face contact rate and its potential application to predicting respiratory tract infection. Journal of Occupational and Environmental Hygiene 5(6):347-352.

104. Kraay ANM, et al. (2021) Risk for Fomite-Mediated Transmission of SARS-CoV-2 in Child Daycares, Schools, Nursing Homes, and Offices. Emerg Infect Dis 27(4):1229-1231.

105. De Albuquerque N, et al. (2006) Murine hepatitis virus strain 1 produces a clinically relevant model of severe acute respiratory syndrome in A/J mice. J Virol 80(21):10382-10394.

106. Dediego ML, et al. (2008) Pathogenicity of severe acute respiratory coronavirus deletion mutants in hACE-2 transgenic mice. Virology 376(2):379-389.

107. Pouillot R \& Delignette-Muller ML (2010) Evaluating variability and uncertainty separately in microbial quantitative risk assessment using two R packages. International journal of food microbiology 142(3):330-340.

108. Atrubin D, Wiese M, \& Bohinc B (2020) An Outbreak of COVID-19 Associated with a Recreational Hockey Game - Florida, June 2020. MMWR Morb Mortal Wkly Rep 69(41):1492-1493.

109. Hamner L, et al. (2020) High SARS-CoV-2 Attack Rate Following Exposure at a Choir Practice Skagit County, Washington, March 2020. MMWR Morb Mortal Wkly Rep 69(19):606-610.

110. Wei J \& Li Y (2015) Enhanced spread of expiratory droplets by turbulence in a cough jet. Building and Environment 93(P2):86-96.

111. Ozkaynak H, Frey HC, Burke J, \& Pinder RW (2009) Analysis of coupled model uncertainties in source-to-dose modeling of human exposures to ambient air pollution: A PM(2.5) case study. Atmos Environ (1994) 43(9):1641-1649.

112. United States Environmental Protection A (2020) List N: Disinfectants for Coronavirus (COVID19). Pesticide Registration:2020-2020.

113. Grove SF, et al. (2015) Norovirus cross-contamination during preparation of fresh produce. International Journal of Food Microbiology 198:43-49. 
medRxiv preprint doi: https://doi.org/10.1101/2021.05.14.21257244; this version posted May 18, 2021. The copyright holder for this preprint (which was not certified by peer review) is the author/funder, who has granted medRxiv a license to display the preprint in perpetuity.

Figures and Tables

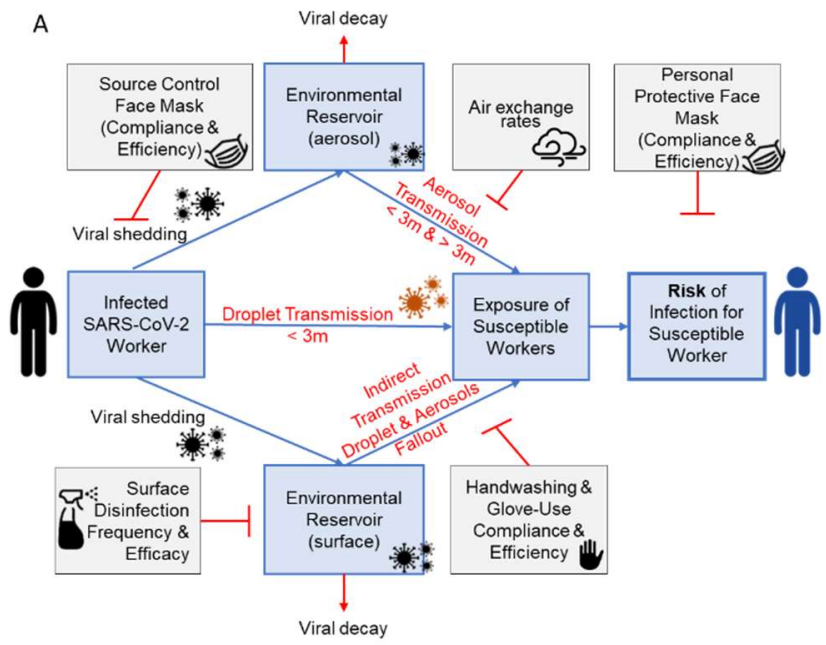

B

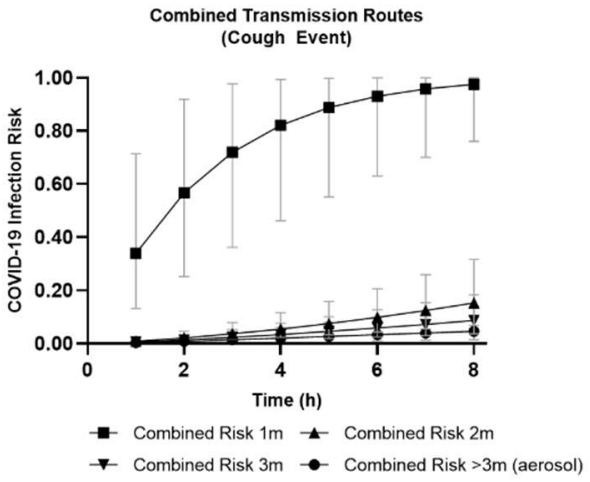

Figure 1. A-B. SARS-CoV-2 QMRA schematic for respiratory event (coughing versus breathing) and infection risk through aerosol, close contact (1-3m, droplet and aerosol), and fomite-mediated transmission assuming no risk mitigation interventions. A. This conceptual model depicts the three transmission pathways (close contact [droplet and aerosol], aerosol, and fomite-mediated) within a representative food manufacturing facility, initiating with a single infected worker either coughing (symptomatic) or breathing (asymptomatic) to generate virus-containing respiratory droplets and aerosols. Droplets fall rapidly due to gravitational forces and were categorized by size and distance traveled from source based on empirical experiments and modeling studies $(75,110):<1 \mathrm{~m}(50-750 \mu \mathrm{m}), 1-2 \mathrm{~m}(50-100 \mu \mathrm{m})$, and 2-3m $(50-60 \mu \mathrm{m})$. Aerosols were defined as $<50 \mu \mathrm{m}$ in diameter with the ability to become aerosolized and remain suspended in the air throughout the entire facility space. B. Infection risk from combined transmission events (aerosol, droplet, fomite-mediated) in association with exposure to an infected worker (coughing) over a period of 1$8 \mathrm{~h}$ and as a function of distance. 
medRxiv preprint doi: https://doi.org/10.1101/2021.05.14.21257244; this version posted May 18, 2021. The copyright holder for this preprint (which was not certified by peer review) is the author/funder, who has granted medRxiv a license to display the preprint in perpetuity.

It is made available under a CC-BY-NC-ND 4.0 International license .

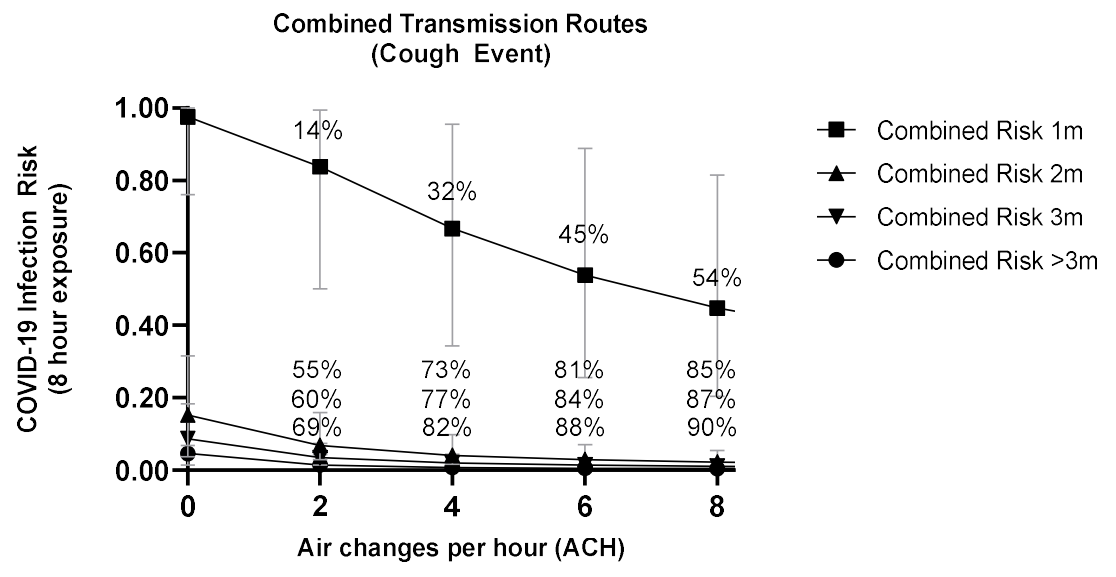

Figure 2. Impact of increasing air exchange on combined infection risk reduction following an 8h-exposure to an infected worker (coughing) at various distances. For reference, air changes per hour (ACH) of 2-6 are representative of typical indoor food manufacturing facilities based on survey results. Included percentages represent the percent reduction in SARS-CoV-2 infection risk relative to no air exchange (baseline $\mathrm{ACH}=$ 0.1 ) for combined risk at the four distances ( $1 \mathrm{~m}, 2 \mathrm{~m}, 3 \mathrm{~m}$, and $>3 \mathrm{~m})$ modeled. 
medRxiv preprint doi: https://doi.org/10.1101/2021.05.14.21257244; this version posted May 18, 2021. The copyright holder for this preprint (which was not certified by peer review) is the author/funder, who has granted medRxiv a license to display the preprint in perpetuity.

It is made available under a CC-BY-NC-ND 4.0 International license .

Table 1. Relative contributions (as a percentage) of droplet, aerosol, and fomite-mediated transmission modes to the cumulative SARS-CoV-2 viral load as a function of distance from initiating transmission events (coughing) and exposure time ( $1 \mathrm{~h}$ or $8 \mathrm{~h}$ ).

\begin{tabular}{lllll}
\hline Time (h) & $1 \mathrm{~m}$ & $2 \mathrm{~m}$ & $3 \mathrm{~m}$ & $\begin{array}{l}\text { Combined viral } \\
\text { load (PFU) } \leq 3 \mathrm{~m}\end{array}$
\end{tabular}

\begin{tabular}{lcccc}
\hline Ih & & & & \\
Droplet & $98.4 \%$ & $47.9 \%$ & $31.2 \%$ & 60.6 \\
Aerosol & $0.8 \%$ & $42.4 \%$ & $64.7 \%$ & 1.5 \\
Fomite & $0.8 \%$ & $9.7 \%$ & $4.1 \%$ & 0.6
\end{tabular}

Absolute viral load (total

PFU) at each distance $\quad 60.7 \quad 1.2 \quad 0.8$

\begin{tabular}{lcccc} 
8h & & & & \\
Droplet & $90.4 \%$ & $20.6 \%$ & $16.4 \%$ & 484.5 \\
Aerosol & $1.3 \%$ & $31.4 \%$ & $58.6 \%$ & 21.0 \\
Fomite & $8.3 \%$ & $47.9 \%$ & $25.0 \%$ & 57.5 \\
$\begin{array}{l}\text { Absolute viral load (total } \\
\text { PFU) at each distance }\end{array}$ & 528.8 & 22.2 & 11.9 & \\
\hline
\end{tabular}


Table 2. Impact of mask use on combined infection risk following 8h cumulative exposure to an infected worker (coughing) as a function of distance. Impact of mask interventions on infection risk $(95 \% \mathrm{Cl})$ and percent risk reduction $(\%)$

\begin{tabular}{|c|c|c|c|c|c|}
\hline & $1 \mathrm{~m}$ & $2 m$ & $3 m$ & Aerosols & $\begin{array}{l}\text { Average } \\
\text { Percent } \\
\text { Risk } \\
\text { Reduction }\end{array}$ \\
\hline \multirow[t]{2}{*}{ No Mask } & Risk $(95 \% \mathrm{Cl}) 0.98(0.76-0.99)$ & $0.15(0.07-0.32)$ & $0.09(0.04-0.18)$ & $0.05(0.01-0.13)$ & \\
\hline & --- & --- & --- & --- & -- \\
\hline \multirow[t]{2}{*}{ Cloth } & Risk $(95 \% \mathrm{Cl}) 0.47(0.20-0.87)$ & $0.04(0.02-0.10)$ & $0.02(0.007-0.05)$ & $0.007(0.001-0.03)$ & \\
\hline & $\%$ Reduction $51.8 \%$ & $73.8 \%$ & $79.0 \%$ & $85.3 \%$ & $72.6 \%$ \\
\hline \multirow[t]{2}{*}{ Surgical } & Risk (95\% Cl)0.35 (0.12-0.76) & $0.03(0.01-0.09)$ & $0.01(0.005-0.04)$ & $0.004(0.0004-0.02)$ & \\
\hline & $\%$ Reduction $64.1 \%$ & $80.4 \%$ & $83.6 \%$ & $90.5 \%$ & $79.1 \%$ \\
\hline \multirow[t]{2}{*}{ Double mask } & ${ }^{*}$ Risk (95\% Cl)0.12 (0.03-0.55) & $0.01(0.002-0.054)$ & $0.004(0.001-0.021)$ & $0.001(0.000-0.01)$ & \\
\hline & $\%$ Reduction $87.7 \%$ & $93.3 \%$ & $95.4 \%$ & $97.7 \%$ & $93.7 \%$ \\
\hline \multirow[t]{2}{*}{ N95 } & Risk $(95 \% \mathrm{Cl}) 0.01(0.004-0.02)$ & $0.0009(0.0003-0.002)$ & $0.0004(0.0001-0.0009)$ & $0.0001(0.00003-0.0003)$ & \\
\hline & \% Reduction $98.9 \%$ & $99.4 \%$ & $99.6 \%$ & $99.8 \%$ & $99.4 \%$ \\
\hline
\end{tabular}

${ }^{\overline{ }}$ Double masking defined as surgical mask layered underneath a cloth mask. 
Table 3. Impact of bundled interventions (mask use, ventilation, hourly handwashing and surface disinfection twice per shift [4h and 8h]) on infection risk $(95 \% \mathrm{Cl})$ and percent risk reduction $(\%)$ following $8 \mathrm{~h}$ cumulative exposure to an infected worker (cough event as a function of distance). Colors indicate risk level from each bundled package. Dark purple indicates a high relative level of risk $(>0.25-1.0)$, medium purple indicates a moderate relative level of risk (0.01-0.25), and light purple indicates a low relative level of risk $(<0.01)$.

\begin{tabular}{|c|c|c|c|c|c|c|}
\hline & & Relative & vel of risk: & High $(>0.25-1.0)$ & Moderate (0.01-0.25) & Low $(<0.01)$ \\
\hline & & & $1 \mathrm{~m}$ & $2 m$ & $3 m$ & Aerosols \\
\hline No ACH & No mask & Risk $(95 \% \mathrm{Cl})$ & $0.98(0.76-0.99)$ & $0.15(0.07-0.32)$ & $0.09(0.04-0.18)$ & $0.05(0.01-0.13)$ \\
\hline & & & --- & --- & --- & --- \\
\hline $2 \mathrm{ACH}$ & Cloth mask & Risk $(95 \% \mathrm{Cl})$ & $0.22(0.06-0.61)$ & $0.005(0.002-0.01)$ & $0.004(0.001-0.01)$ & $0.002(0.0005-0.009)$ \\
\hline & & $\%$ Reduction & $77.6 \%$ & $96.6 \%$ & $95.9 \%$ & $95.5 \%$ \\
\hline & Surgical & Risk $(95 \% \mathrm{Cl})$ & $0.14(0.02-0.47)$ & $0.003(0.0009-0.01)$ & $0.002(0.0005-0.007)$ & $\mathbf{0 . 0 0 1}(0.0001-0.006)$ \\
\hline & & \% Reduction & $86.0 \%$ & $97.8 \%$ & $97.4 \%$ & $97.1 \%$ \\
\hline & Double mask & Risk $(95 \% \mathrm{Cl})$ & $0.04(0.005-0.30)$ & $0.001(0.0002-0.005)$ & $0.0007(0.0001-0.004)$ & $0.0003(0.00003-0.003)$ \\
\hline & & $\%$ Reduction & $96.2 \%$ & $99.3 \%$ & $99.2 \%$ & $99.3 \%$ \\
\hline $6 \mathrm{ACH}$ & Cloth mask & Risk $(95 \% \mathrm{Cl})$ & $0.10(0.02-0.33)$ & $0.002(0.0007-0.006)$ & $0.001(0.0005-0.004)$ & $0.001(0.0002-0.003)$ \\
\hline & & $\%$ Reduction & $89.8 \%$ & $98.6 \%$ & $98.3 \%$ & $98.2 \%$ \\
\hline & Surgical & Risk $(95 \% \mathrm{Cl})$ & $0.06(0.009-0.24)$ & $0.001(0.0004-0.004)$ & $0.001(0.0002-0.003)$ & $0.001(0.00005-0.002)$ \\
\hline & & \% Reduction & $93.8 \%$ & $99.1 \%$ & $98.9 \%$ & $98.8 \%$ \\
\hline & Double mask & Risk $(95 \% \mathrm{Cl})$ & $0.02(0.002-0.14)$ & $0.0004(0.00007-0.002)$ & $0.0003(0.00004-0.002)$ & $0.0001(0.00001-0.001)$ \\
\hline & & \% Reduction & $98.4 \%$ & $99.7 \%$ & $99.7 \%$ & $99.7 \%$ \\
\hline
\end{tabular}


